Proc. Estonian Acad. Sci. Geol., 2000, 49, 3, 218-243

\title{
DIATOM STRATIGRAPHY AND PALAEOENVIRONMENT OF THE YOLDIA SEA IN NORTHERN ESTONIA
}

\begin{abstract}
Atko HEINSALU
Institute of Geology, Tallinn Technical University, Estonia pst. 7, 10143 Tallinn, Estonia; heinsalu@gi.ee

Received 21 December 1999, in revised form 23 February 2000

Abstract. The palaeoenvironment of the Yoldia Sea is reconstructed on the basis of 20 diatom stratigraphic records from northern Estonia. The development of the Yoldia Sea is divided into three phases. The initial Yoldia Sea phase (c. $10300-9900{ }^{14} \mathrm{C}$ years BP) is characterized by a freshwater environment. Brackish-water conditions prevailed during a short period (c. $9900-9750$ ${ }^{14} \mathrm{C}$ years $\mathrm{BP}$ ) along the north coast of Estonia in the middle phase of the Yoldia Sea stage. During the final phase of the Yoldia Sea (c. $9750-9500{ }^{14} \mathrm{C}$ years BP) a freshwater environment is registered by diatom assemblages. Regression of the shoreline, for at least $25 \mathrm{~m}$, occurred around Tallinn during the Yoldia Sea stage. Postisolation coastal lakes are characterized by a shallow eutrophic hard-water environment.
\end{abstract}

Key words: diatom stratigraphy, chrysophyte cysts, palaeosalinity, shoreline displacement, Yoldia Sea, Baltic Sea, Estonia.

\section{INTRODUCTION}

General features of the late- and postglacial development of the Baltic Sea are rather well known. However, many questions are still unresolved, particularly concerning the salinity of the Yoldia Sea, in the eastern part of the Baltic basin. The name, Yoldia Sea, derives from a marine bivalve Portlandia (Yoldia) arctica, present in glacial varved clays in the vicinity of Stockholm (De Geer 1913). The Yoldia Sea stage is defined as the period when the ocean was connected to the Baltic basin across southern central Sweden and water levels of both water bodies became equal after the drainage of the Baltic Ice Lake (Björck 1995). The onset of the Yoldia Sea started when the drainage of the Baltic Ice Lake had taken place at $10300{ }^{14} \mathrm{C}$ years BP (Svensson 1989) and the water level had dropped c. 25-28 m (Björck 1979; Donner 1982). The Yoldia Sea came to an end with the beginning of the Ancylus Lake transgression at $9500{ }^{14} \mathrm{C}$ years $\mathrm{BP}$ (Eronen \& 
Haila 1982). According to palaeosalinity records from Sweden and the Baltic Sea proper, the Yoldia Sea history has been divided into three phases, with the brackish conditions during the middle phase (Svensson 1989; Wastegård et al. 1995). The initial $300{ }^{14} \mathrm{C}$ years of the Yoldia Sea were characterized by freshwater conditions (Svensson 1989). Brackish-water conditions lasted presumably for a short time, for 100-200 years (Svensson 1991; Wastegård et al. 1995). Diatom records indicate that the brackish-water conditions of the Yoldia Sea existed close to the saline inflow area in southern central Sweden (Robertson 1990), in the Landsort Deep (Lepland et al. 1999), in the Karlsö basin (Abelmann 1985), and in the Gotland Deep (Andrén et al. 2000). Furthermore, the records of calcareous fossils, such as the arctic mollusc Portlandia arctica (Brunnberg 1995; Björck et al. accepted) as well as benthic ostracods and foraminifera (Wastegård \& Schoning 1997; Wastegård et al. 1998), demonstrate bottom-water salinity of the Yoldia Sea in eastern central Sweden and the northwestern Baltic Sea.

The balance between the saline water intrusion and the freshwater discharge from the rapidly melting ice sheet determined how far east into the Baltic basin saline water could have reached from the inflow area. The offshore sediments in the Gulf of Finland are barren or poor in diatoms; among these, the freshwater planktonic diatom Aulacoseira islandica occurs (Åker et al. 1988). Furthermore, in Finland the diatom composition of the Yoldia Sea sediment is often ecologically mixed, featuring both freshwater and salt-water forms with the freshwater species generally predominant, and an overall low diatom abundance (Hyvärinen \& Eronen 1979). Eronen (1974), therefore, concluded that the importance of saline water is overestimated north of the Salpausselkä end moraine zone close to the retreating ice margin. Moreover, based on the occurrence of marine diatoms in the clays accumulated near the ice margin, he suggested redeposition of salt-water diatoms from interglacial deposits. Indeed, similar polyhalobous and mesohalobous diatoms and also silicoflagellates have been found and described in the Eemian marine interglacial sequences in Finland (Grönlund 1991). Several studies in southern Finland have shown that a relatively large number of brackish-water diatoms occur in the Yoldia Sea sediments (e.g. Sauramo 1958; Valovirta 1965; Ristaniemi \& Glückert 1987). These records seem to support the opinion that the pulse of brackish water penetrated into the coastal area of southern Finland during the Yoldia Sea (Eronen 1983).

In northern Estonia several sediment sequences from small lake and bog basins, presumably isolated during Younger Dryas and/or Early Pre-Boreal times, were investigated by means of pollen analysis (e.g. Veski 1998). Unfortunately there are still only a few palaeosalinity records from that area. Lagoonal deposits of the Sõjamäe basin contain single fragments of brackish-water and freshwater diatoms (Kessel \& Punning 1969). Diatom assemblages with a mixture of polyhalobous, mesohalobous, and oligohalobous taxa have been found in eight deep cores, reflecting the Yoldia Sea water depth of approximately between 70 and 25 m (Kessel \& Punning 1969; Kessel \& Pork 1971). Although the 
abundance of diatoms in these sediments is small and quantitative estimations were carried out only at two sites, the deposits were correlated with the Yoldia Sea, which led to an estimate of the salinity of the basin as 5-8\%o (Kessel \& Raukas 1979). Recently a new site, the Tondi Mire, was investigated where only very weak brackish-water conditions in the littoral environment of the Yoldia Sea were recognized (Lepland et al. 1995). An alternative view of the Yoldia Sea sediment records has been expressed by Hyvärinen et al. (1992) and Raukas $(1994,1995)$, who claim that salt water influx did not reach the eastern part of the Baltic basin and the Gulf of Finland. The presence of brackish-water diatoms in the Yoldia Sea sediments is explained by redeposition.

The purpose of the present work is therefore to provide new and detailed information on the Yoldia Sea palaeoenvironment in northern Estonia. Altogether, 32 basins from various altitudes above sea level (a.s.l.) were examined and here diatom stratigraphy of 20 isolation basins is described. Diatom records from seven sites, where preisolation sediments are devoid of diatoms and/or the siliceous microfossils are weakly preserved, are presented in the Appendix.

\section{GEOLOGICAL SETTING}

The study area (Fig. 1) is located on the southern slope of the Fennoscandian Shield where bedrock consists of terrigenous Cambrian and calcareous Ordovician rocks. A remarkable escarpment, the North Estonian Klint (the Baltic Klint), divides the area into the foreklint lowland and a flat limestone plateau on the klint. Glacial erosion has dissected the klint face into protruding klint headlands and north to south orientated klint embayments which are often associated with pre-Quaternary buried valleys. The topography along the limestone plateau is generally flat and overlain by a thin Quaternary cover. The present land uplift rate in northern Estonia is approximately $1 \mathrm{~mm} /$ year. During the Younger Dryas and the Pre-Boreal transition the uplift rate was considerably faster, c. $3 \mathrm{~cm} /$ year around Tallinn (Kessel \& Miidel 1973), and the shoreline regression, therefore, was fairly rapid. In the study area the interpolated shoreline, prior to the final drainage of the Baltic Ice Lake, is at $68 \mathrm{~m}$ a.s.l. in the east and at $80 \mathrm{~m}$ a.s.l. in the west (Kessel 1961a). Taking into consideration that during the drainage of the Baltic Ice Lake the water level dropped c. $25 \mathrm{~m}$, the oldest Yoldia Sea shoreline is estimated at c. $50 \mathrm{~m}$ a.s.l. During the Yoldia Sea the sea level dropped at least to $28 \mathrm{~m}$ a.s.l. around Tallinn (Saarse et al. 1997). The Ancylus Lake transgression maximum reached an altitude of 33-32 m a.s.l. in the western part of the study area and $34 \mathrm{~m}$ a.s.l. in the east (Veski 1998) and partly inundated the Yoldia Sea deposits. Therefore, the basins with the threshold elevations between 50 and $30 \mathrm{~m}$ a.s.l. were selected for the current research. The description of the investigated basins is presented in Table 1 . 


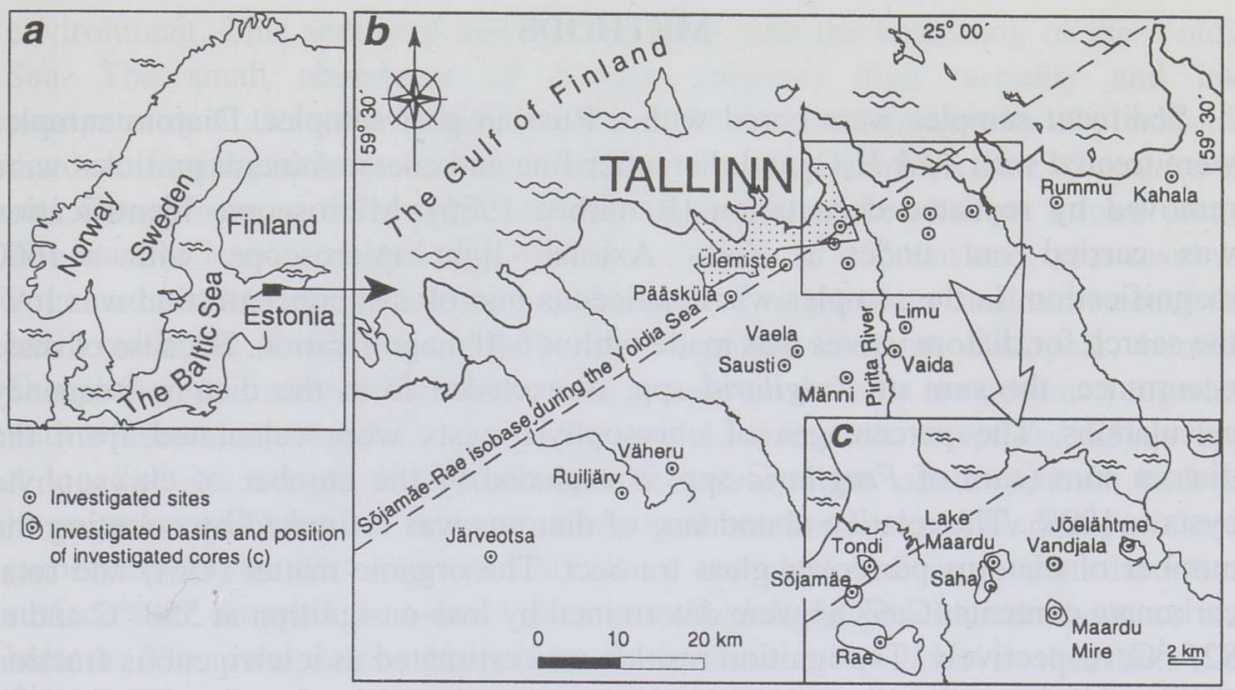

Fig. 1. Location of the investigated sites: (a) the Baltic region, (b) the study area in northern Estonia, (c) the investigated basins east of Tallinn.

Table 1. Description of the sites investigated in northern Estonia by means of diatom analysis. The sites included in the Appendix are marked with the asterisk

\begin{tabular}{|c|c|c|c|c|c|c|c|}
\hline Site & $\begin{array}{l}\text { Latitude, } \\
\text { N }\end{array}$ & Longitude, & $\begin{array}{c}\text { Altitude, } \\
\text { a.s.l., } \\
\text { m }\end{array}$ & \begin{tabular}{|} 
Threshold \\
altitude, \\
a.s.l., m
\end{tabular} & $\begin{array}{l}\text { Water } \\
\text { depth, } \\
\text { cm }\end{array}$ & $\begin{array}{l}\text { Sediment } \\
\text { column, } \\
\mathrm{cm}\end{array}$ & $\begin{array}{l}\text { Section of the } \\
\text { core analysed, } \\
\mathrm{cm}\end{array}$ \\
\hline Lake Väheru* & $59^{\circ} 11^{\prime} 30^{\prime \prime}$ & $24^{\circ} 32^{\prime} 45^{\prime \prime}$ & 45 & 47 & 10 & 430 & $435-390$ \\
\hline Männi Bog & $59^{\circ} 17^{\prime} 00^{\prime \prime}$ & $24^{\circ} 54^{\prime} 30^{\prime \prime}$ & 47.5 & 43 & - & 805 & $805-760$ \\
\hline Vaida Mire* & $59^{\circ} 18^{\prime} 30^{\prime \prime}$ & $24^{\circ} 57^{\prime} 15^{\prime \prime}$ & 42 & 41 & - & 370 & $370-275$ \\
\hline Lake Ruiljärv* & $59^{\circ} 10^{\prime} 30^{\prime \prime}$ & $24^{\circ} 26^{\prime} 00^{\prime \prime}$ & 42 & 42 & 70 & 400 & $467-422$ \\
\hline Vaela Mire* & $59^{\circ} 19^{\prime} 00^{\prime \prime}$ & $24^{\circ} 47^{\prime} 30^{\prime \prime}$ & 45.5 & 41 & - & 550 & $545-500$ \\
\hline Lake Limu & $59^{\circ} 20^{\prime} 20^{\prime \prime}$ & $24^{\circ} 59^{\prime} 50^{\prime \prime}$ & 38.5 & 39 & 20 & 495 & $510-380$ \\
\hline Lake Järveotsa* & $59^{\circ} 05^{\prime} 45^{\prime \prime}$ & $24^{\circ} 09^{\prime} 15^{\prime \prime}$ & 41 & 41 & 265 & 610 & $830-778$ \\
\hline Lake Rummu & $59^{\circ} 27^{\prime} 10^{\prime \prime}$ & $25^{\circ} 17^{\prime} 10^{\prime \prime}$ & 36 & 37 & 30 & 565 & $580-405$ \\
\hline Maardu Mire* & $59^{\circ} 24^{\prime} 45^{\prime \prime}$ & $25^{\circ} 02^{\prime} 20^{\prime \prime}$ & 40 & 37.5 & - & 285 & $270-235$ \\
\hline Lake Kahala & $59^{\circ} 29^{\prime} 30^{\prime \prime}$ & $25^{\circ} 32^{\prime} 00^{\prime \prime}$ & 32.5 & 33.5 & 80 & 770 & $770-80$ \\
\hline Sausti Mire & $59^{\circ} 17^{\prime} 40^{\prime \prime}$ & $24^{\circ} 45^{\prime} 00^{\prime \prime}$ & 37.5 & 37 & - & 485 & $485-380$ \\
\hline Vandjala Mire & $59^{\circ} 26^{\prime} 20^{\prime \prime}$ & $25^{\circ} 03^{\prime} 00^{\prime \prime}$ & $?$ & 37.5 & - & c. 300 & $60-0$ \\
\hline Tondi site & $59^{\circ} 26^{\prime} 30^{\prime \prime}$ & $24^{\circ} 51^{\prime} 40^{\prime \prime}$ & 41 & 38.5 & - & 365 & $360-290$ \\
\hline Rae Mire & $59^{\circ} 24^{\prime} 15^{\prime \prime}$ & $24^{\circ} 51^{\prime} 45^{\prime \prime}$ & 41 & 37.5 & - & 750 & $745-550$ \\
\hline Sõjamäe site & $59^{\circ} 25^{\prime} 45^{\prime \prime}$ & $24^{\circ} 50^{\prime} 10^{\prime \prime}$ & 41 & 37.8 & - & 285 & $225-180$ \\
\hline Saha Mire & $59^{\circ} 25^{\prime} 45^{\prime \prime}$ & $24^{\circ} 59^{\prime} 15^{\prime \prime}$ & 34 & 34 & - & 235 & $235-175$ \\
\hline Jõelähtme site* & $59^{\circ} 27^{\prime} 20^{\prime \prime}$ & $25^{\circ} 08^{\prime} 40^{\prime \prime}$ & 30 & 32 & - & 180 & $175-60$ \\
\hline Pääsküla Mire & $59^{\circ} 21^{\prime} 15^{\prime \prime}$ & $24^{\circ} 40^{\prime} 00^{\prime \prime}$ & 34 & 34 & - & 600 & $595-360$ \\
\hline Lake Maardu & $59^{\circ} 26^{\prime} 30^{\prime \prime}$ & $24^{\circ} 59^{\prime} 30^{\prime \prime}$ & 32 & 32 & 200 & 775 & $995-845$ \\
\hline Lake Ülemiste & $59^{\circ} 23^{\prime} 30^{\prime \prime}$ & $24^{\circ} 46^{\prime} 15^{\prime \prime}$ & 36 & 31.5 & 320 & 430 & $750-630$ \\
\hline
\end{tabular}




\section{METHODS}

Sediment samples were cored with a Russian peat sampler. Diatom samples were treated with $30 \% \mathrm{H}_{2} \mathrm{O}_{2}$ and thereafter fine and coarse mineral particles were removed by repeated decantation (Battarbee 1986). Microscopic identification was carried out under a Zeiss Axiolab light microscope with $\times 1600$ magnification. In the samples where siliceous microfossil concentration was low, the search for diatom valves was made with $\times 640$ magnification. Because of mass occurrence, the sum of Fragilaria spp. is excluded from the diatom frequency calculations. The percentages of chrysophyte cysts were calculated from the diatom sum (sum of Fragilaria spp. is excluded) + the number of chrysophyte cysts $=100 \%$. The relative abundance of diatoms was estimated by counting the number of diatoms per cover glass transect. The organic matter (OM) and total carbonate contents $\left(\mathrm{CaCO}_{3}\right)$ were determined by loss-on-ignition at $550{ }^{\circ} \mathrm{C}$ and at $825^{\circ} \mathrm{C}$, respectively. The ignition residue was estimated as a terrigenous fraction (TER). All the radiocarbon dates in this paper are expressed as uncalibrated ${ }^{14} \mathrm{C}$ years BP. The altitudes of isolation thresholds were levelled and tied with the nearest bench marks or were estimated from the topographic maps.

\section{DIATOM STRATIGRAPHY}

The Männi Bog is situated east of Nabala village in Harju County (Fig. 1). The isolation threshold lies west of the bog and is estimated at $43 \mathrm{~m}$ a.s.l. (Table 1). Large-lake diatoms, such as planktonic Aulacoseira islandica, which flourish in the surface water of large and relatively deep lakes, and periphytic Opephora martyi, Gyrosigma attenuatum, Diploneis domblittensis, and Epithemia frickei are present in low frequencies in the lowermost part of the silt (Fig. 2), indicating a weak connection with the freshwater Yoldia Sea basin. A relatively high number of Fragilaria spp. in the silt also supports the beginning of isolation. The emergence of the Männi basin from the Yoldia Sea took place rapidly and the lagoonal conditions did not develop there. The postisolation diatom assemblage shows a small shallow eutrophic lake environment. At a core-depth of $778 \mathrm{~cm}$ and upwards, an increase in the carbonate content in the sediment is observed together with distinct expansion of diatoms tolerant of calcium-rich water, such as Cymbella ehrenbergii, Navicula oblonga, Caloneis obtusa, and C. latiuscula.

Lake Limu is a small lake in Harju County, northeastward of the Vaida Mire (Fig. 1). An esker borders the lake in the east and northeast. A narrow isolation threshold of the basin is situated to the northeast of the lake and is estimated at $39 \mathrm{~m}$ a.s.l. (Table 1). Planktonic large-lake diatoms Aulacoseira islandica and Stephanodiscus neoastraea constitute up to $80 \%$ of the assemblage in the lower part of the homogenous clay (Fig. 3), indicating a rather deep freshwater 
environment. This sediment unit is correlated with the beginning of the Yoldia Sea. The small abundance of diatoms suggests high turbidity and low transparency of the water column, unfavourable for the productivity of planktonic diatoms. Periphytic large-lake diatoms, e.g. Gyrosigma attenuatum, G. spencerii, and Campylodiscus hibernicus probably derive from the shallow littoral areas. The start of basin isolation is recorded at a depth of $455 \mathrm{~cm}$ and, as a result, a large and shallow coastal lagoon was formed. A very narrow strait connected the basin with the Yoldia Sea. Planktonic large-lake diatoms disappear, benthic Fragilaria spp. increase, and large-lake periphytic diatoms are common together with epipsammic Amphora pediculus and A. thumensis. Amphora libyca and A. ovalis have a wide environmental tolerance and are often common both in large and small lakes. A layer of submerged mosses Scorpidium scorpioides is embedded in the $450-440 \mathrm{~cm}$ interval of the clay, indicating that the water surface had dropped to a level that permitted light penetration down to the bottom. The calciphilous bryophyte Scorpidium scorpioides is distributed in Estonian hard-water lakes with high conductivity (Ingerpuu et al. 1994). The presence of periphytic diatom taxa, e.g. Navicula pseudoscutiformis, $N$. laevissima, Pinnularia interrupta, and Caloneis bacillum, which are common also in the Younger Dryas lacustrine sediments on Suursaari Island (Heinsalu et al. 2000), suggests a cold climate. In the gyttja typical small-lake diatoms predominate.

Lake Rummu is located almost at the same land uplift isobase as Lake Limu (Fig. 1). The threshold of the basin is situated east of the lake at $37 \mathrm{~m}$ a.s.l. (Table 1). Preisolation clayey silt contains almost entirely large-lake diatoms, e.g. Aulacoseira islandica, Diploneis domblittensis, Gyrosigma attenuatum, G. spencerii (Fig. 4), indicating fresh and rather deep water. At a depth of $505 \mathrm{~cm}$ large-lake diatoms start to decline while Fragilaria spp. peak, and small epipsammic diatoms, e.g. Amphora pediculus, appear. A weak connection of the Rummu basin with the freshwater Yoldia Sea through shallow straits seems to have persisted until the accumulation of clayey silt was replaced by silty gyttja. In the silty gyttja epipsammic diatoms and epiphytic Epithemia smithii, Achnanthes minutissima, and Cymbella spp. are most common. The depositional environment of the Rummu basin resembles thus a very shallow lake, with a silty bottom and abundant aquatic macrophytes. The diatom assemblage in the gyttja with calcareous interlayers indicates a small shallow hard-water lake. According to pollen analysis (Veski 1998), the Younger Dryas-Pre-Boreal transition occurs at a depth of $530 \mathrm{~cm}$. An unidentified macrofossil at $500 \mathrm{~cm}$ was dated to $9825 \pm 70{ }^{14} \mathrm{C}$ years BP (Ua-12442) by the accelerator mass spectrometer (AMS) technique. The AMS date $10025 \pm 145{ }^{14} \mathrm{C}$ years BP (Ua-13039) from pollen concentrate at $459 \mathrm{~cm}$ is considerably older than that obtained on this macrofossil (Veski 1998).

Lake Kahala, with the present surface area of 350 ha, is the easternmost site investigated (Fig. 1). The lake lies in the depression of an ancient klint bay and is 
surrounded by klint headlands in the north and west. The threshold of the basin is located southwestwards of the lake on the limestone bedrock surface at an altitude of $33.5 \mathrm{~m}$ a.s.l. (Table 1). According to pollen analysis, the homogenous clay and silt were deposited during the Younger Dryas (Saarse et al. 1999). The preisolation sediments are characterized by a freshwater large-lake diatom assemblage. Planktonic Aulacoseira islandica and Stephanodiscus neoastraea are present in the clay to a core-depth of $640 \mathrm{~cm}$ (Fig. 5). From the $640 \mathrm{~cm}$ level the frequency of the littoral Fragilaria species increases. This event is interpreted as a decrease in the water level of the area and the development of lagoon-like conditions in the basin which was still connected with the Yoldia Sea through shallow straits. During the lagoonal phase of the Kahala basin large-lake periphytic diatoms, e.g. Gyrosigma attenuatum, Diploneis domblittensis, and Opephora martyi, are common. The number of the epipsammic diatoms Amphora pediculus, A. thumensis, Achnanthes clevei, and Cocconeis diminuta increases gradually. The lagoon was very shallow and the silty bottom was probably a suitable substratum for epipsammic diatoms. The final isolation of the basin is recorded at a core-depth of $575 \mathrm{~cm}$. The frequency of large-lake taxa either decreases clearly or they disappear and small-lake diatoms, such as Navicula schoenfeldii and Cymbella diluviana, appear and the loss-on-ignition values increase. The sample above the isolation level at $565-555 \mathrm{~cm}$ was dated to $9725 \pm 80{ }^{14} \mathrm{C}$ years BP (Tln-1936; Saarse et al. 1999). High values of Fragilaria spp. and epipsammic diatoms between 575 and $460 \mathrm{~cm}$ illustrate a low water level and broad sandy littoral area in the lake during the Late Pre-Boreal and the Early Boreal (see pollen diagram in Saarse et al. 1999). A distinct increase in planktonic Aulacoseira ambigua can be related to the rise of the lake-water level and shift towards more humid climatic conditions. This event is dated to $8435 \pm 85{ }^{14} \mathrm{C}$ years BP (Tln-1928). At the same level the expansion of Alnus takes place (Saarse et al. 1999).

The Sausti Mire lies in the southern part of the investigated area (Fig. 1). The threshold of the basin is located to the west of the mire at $37 \mathrm{~m}$ a.s.l. (Table 1). The coring site is situated on the right bank of the Tõdva River, in the part of the mire which is cultivated. In the lower part of the Sausti sequence Gyrosigma attenuatum and Aulacoseira islandica predominate (Fig. 6). The isolation of the basin at a core-depth of $420 \mathrm{~cm}$ is characterized by the disappearance of largelake diatoms, a sharp increase in Fragilaria spp., and the predominance of taxa common in a freshwater lagoon and/or in a shallow coastal lake. In the lake lime diatoms are partially dissolved. Preserved diatoms indicate a hard-water shallow lake environment.

The Vandjala Mire occupies a small basin $2 \mathrm{~km}$ east of Lake Maardu (Fig. 1). The Vandjala basin has two thresholds, one lies to the west and the other to the south, both at an elevation of $37.5 \mathrm{~m}$ a.s.l. (Table 1). Half of the mire has been excavated during phosphorite mining nearby. The samples were taken from a vertical exposure. Pollen analysis showed that the lowermost sand and the 
MÄNNI BOG

Selected diatom taxo, \%
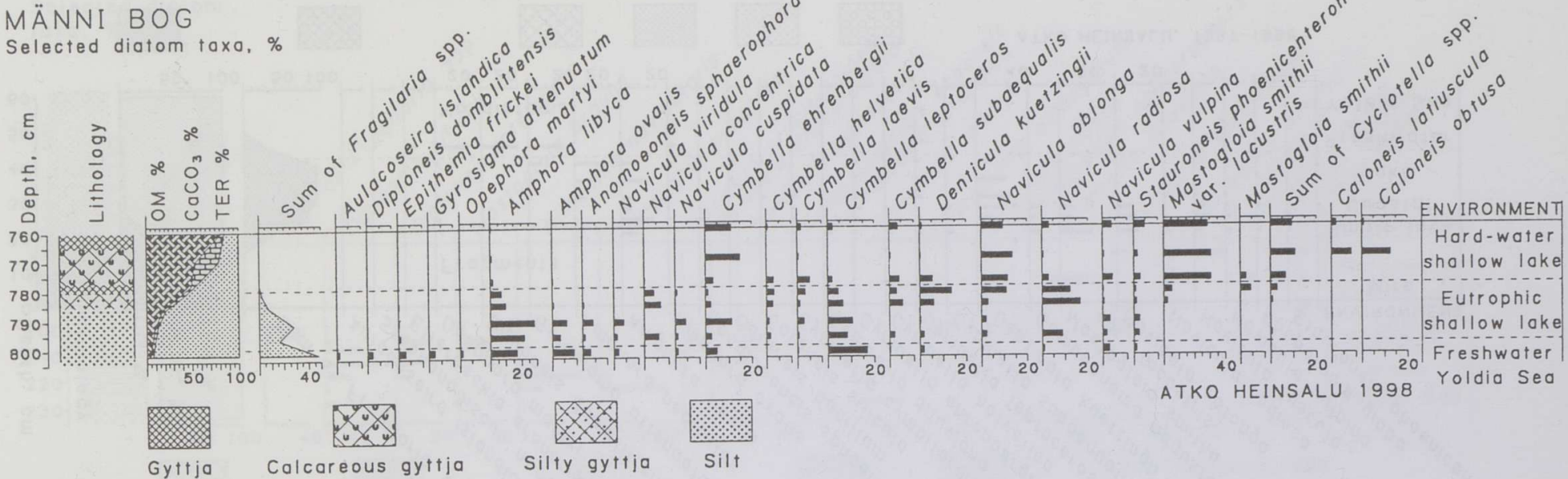

Fig. 2. Diatom diagram of the sediment core from the Männi Bog.

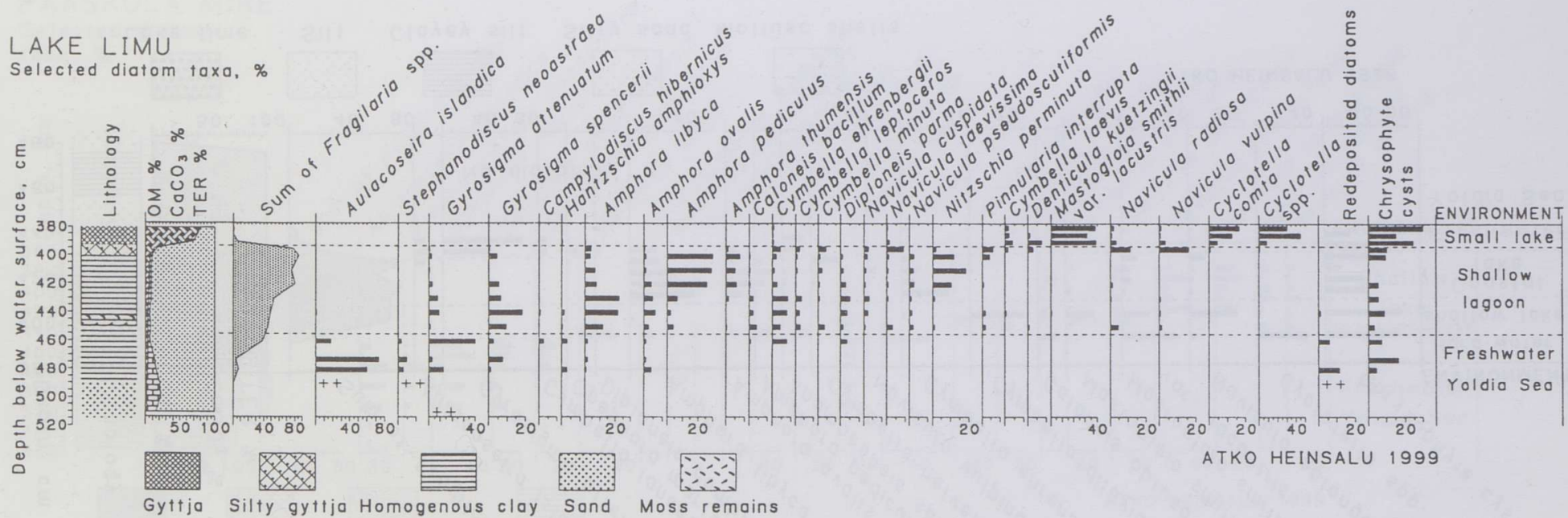

Fig. 3. Diatom diagram of the sediment core from Lake Limu.

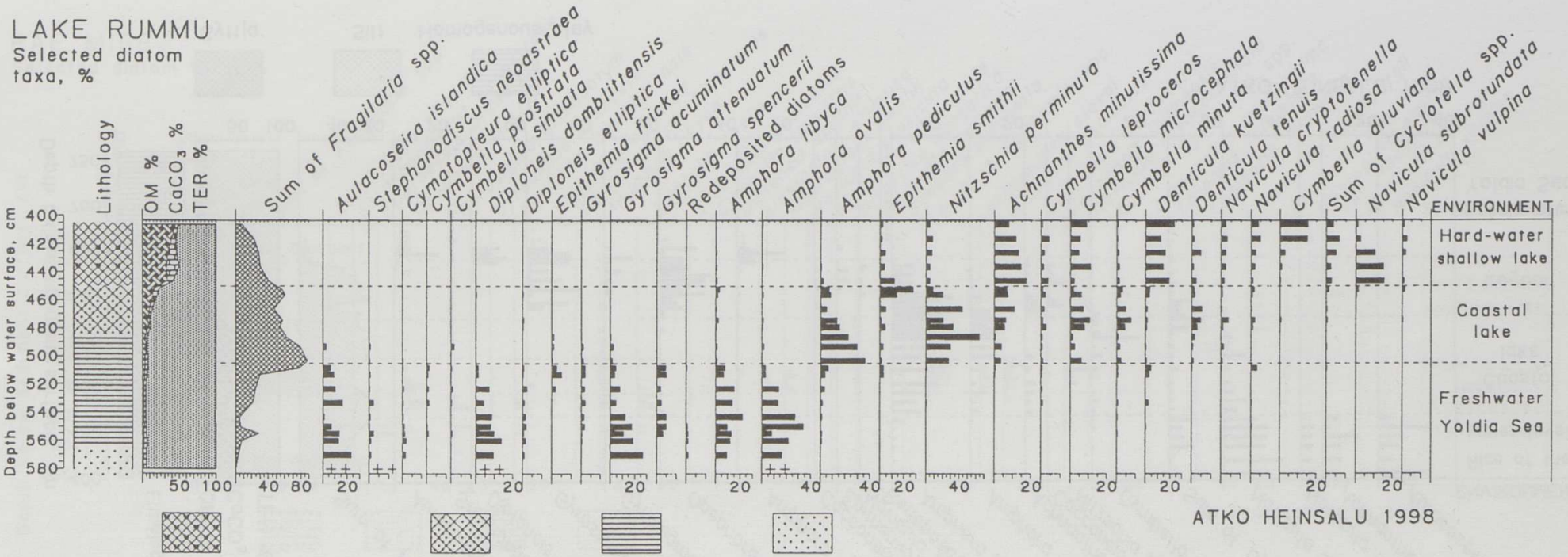

Gytrja with calcareous interlayers Silty gyttja Homogenous clay Sandy silt 
LAKE KAHALA

Selected diatom taxa, \%

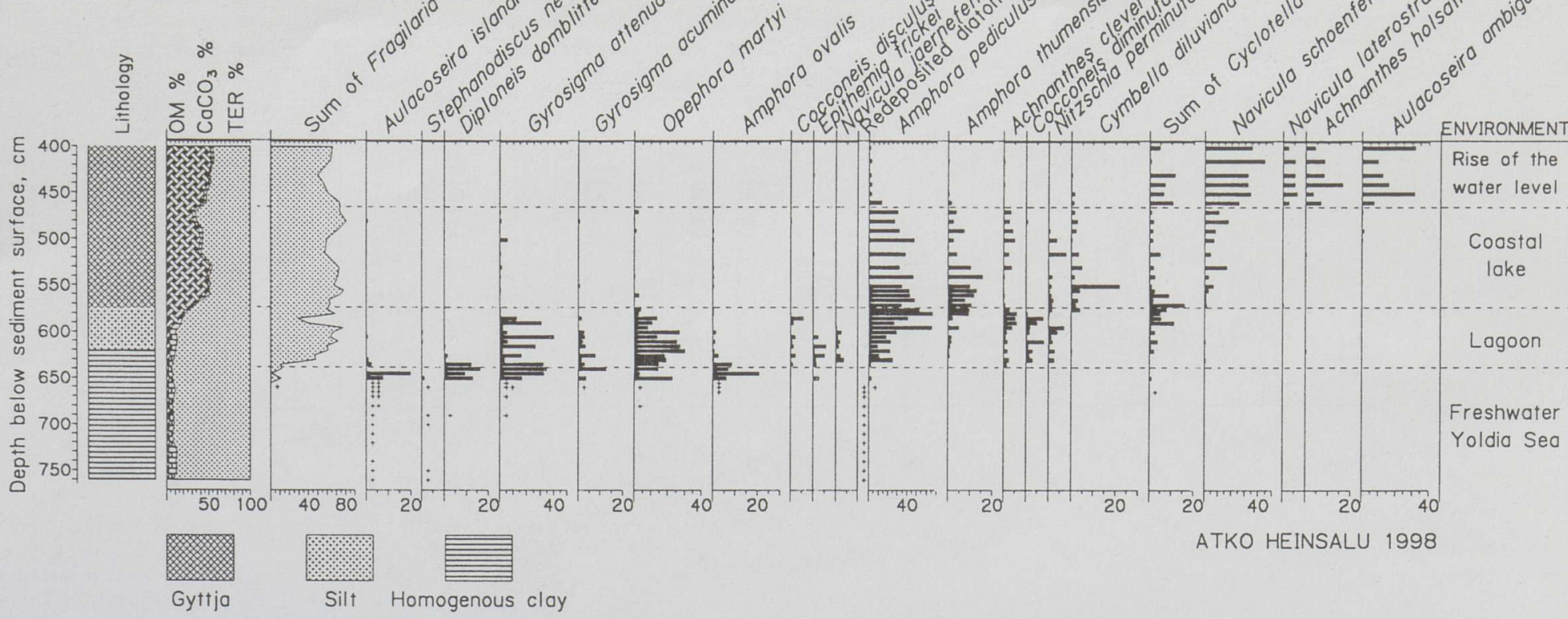

Fig. 5. Diatom diagram of the sediment core from Lake Kahala

\section{SAUSTI MIRE}

Selected diatom taxa, \%

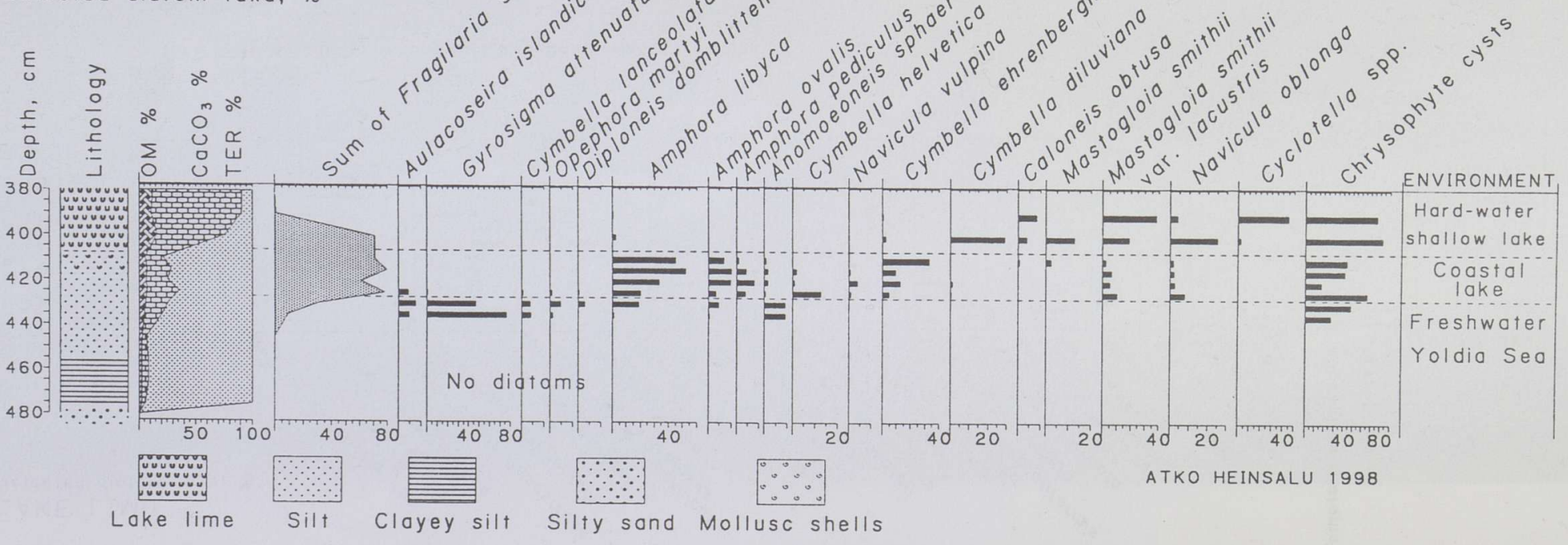

Fig. 6. Diatom diagram of the sediment core from the Sausti Mire

VANDJALA MIRE

Selected diatom toxa, \%

$0 \mathrm{~cm}=37.7 \mathrm{mos} .1$.

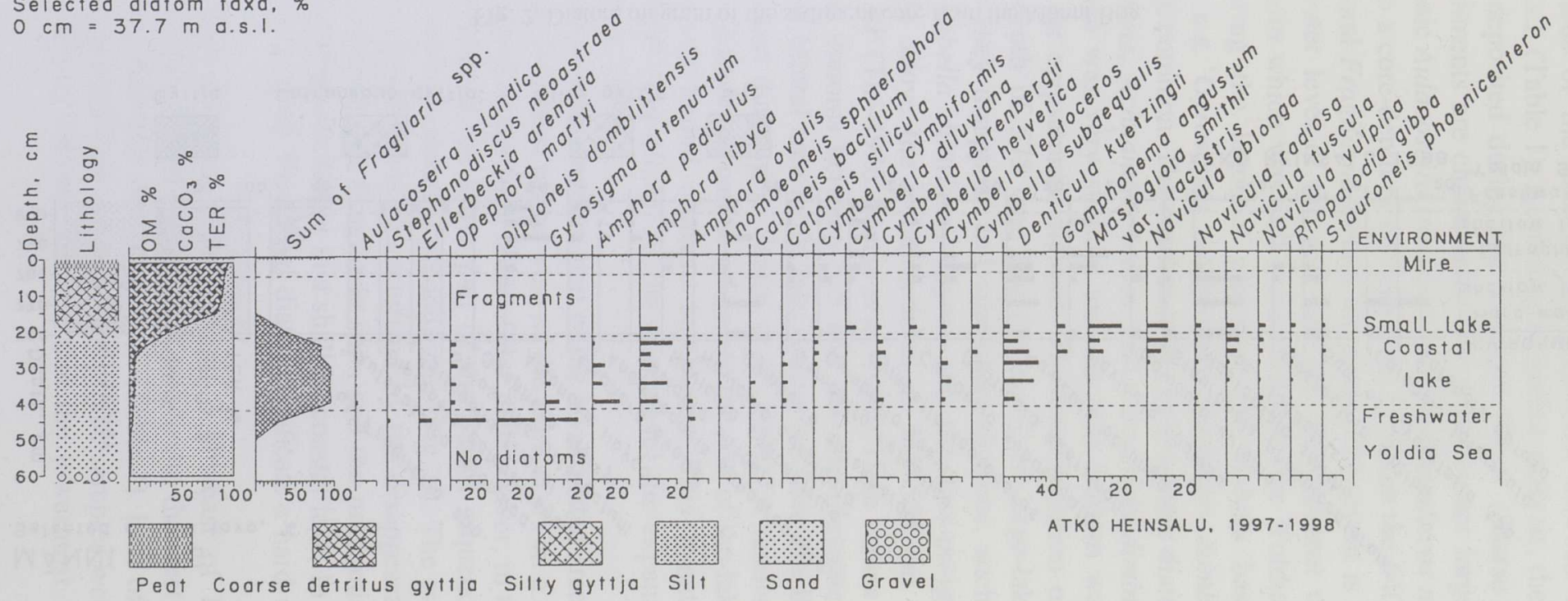

Fig. 7. Diatom diagram of the sediment core from the Vandjala Mire. 


\section{Selected diotom}

$\operatorname{tax} 0, \%$

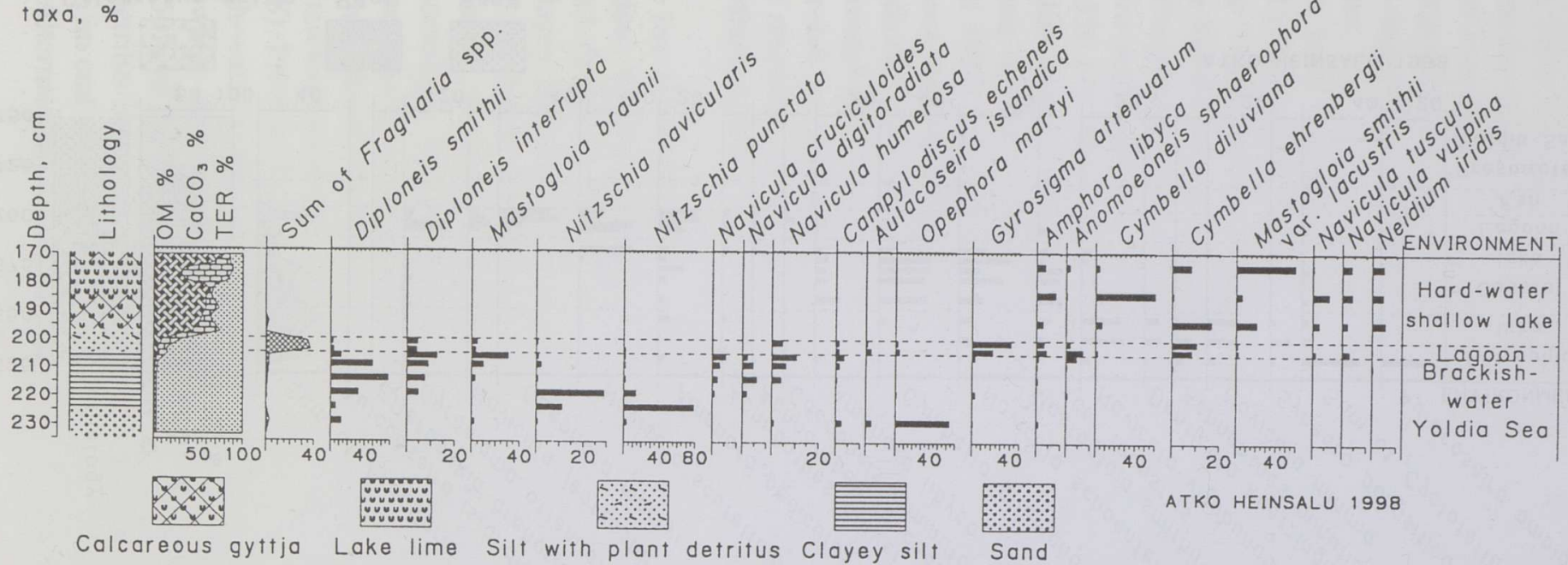

Fig. 8. Diatom diagram of the sediment core from the Saha Mire.

PÄÄSKÜLA MIRE

Selected diotom

taxo, \%

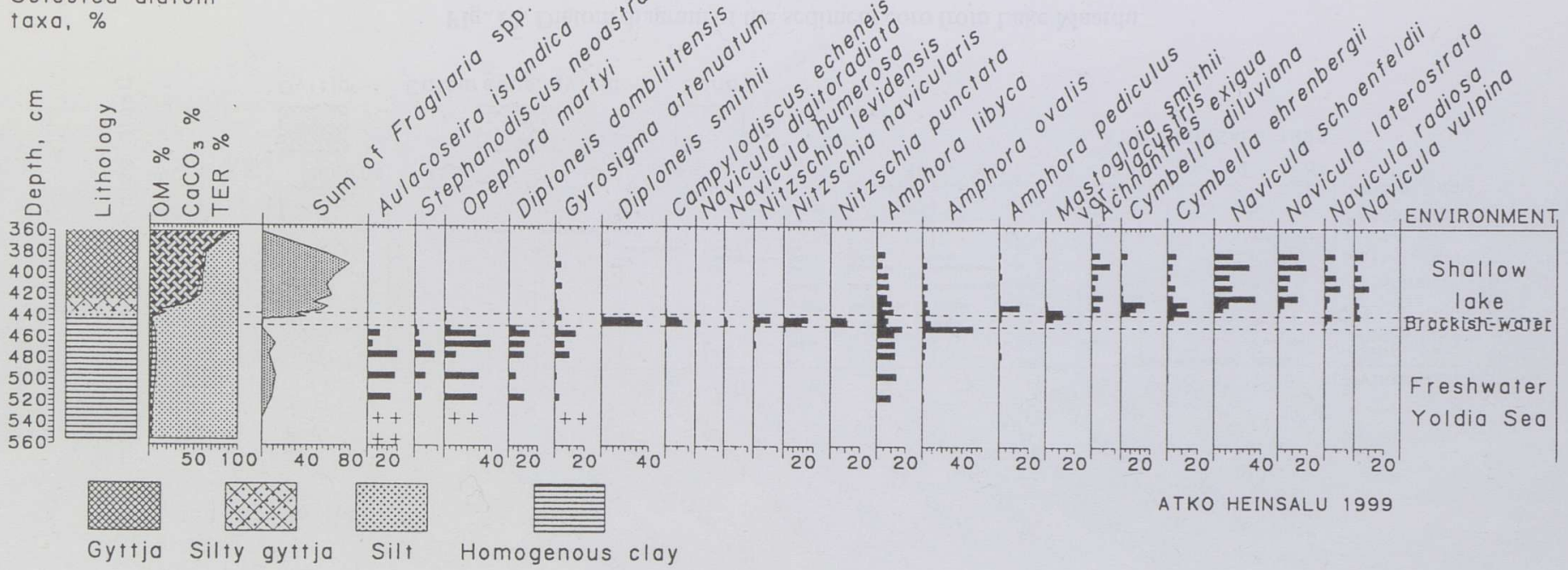

Fig. 9. Diatom diagram of the sediment core from the Pääsküla Mire.

RAE MIRE

Selected diatom taxa, \%

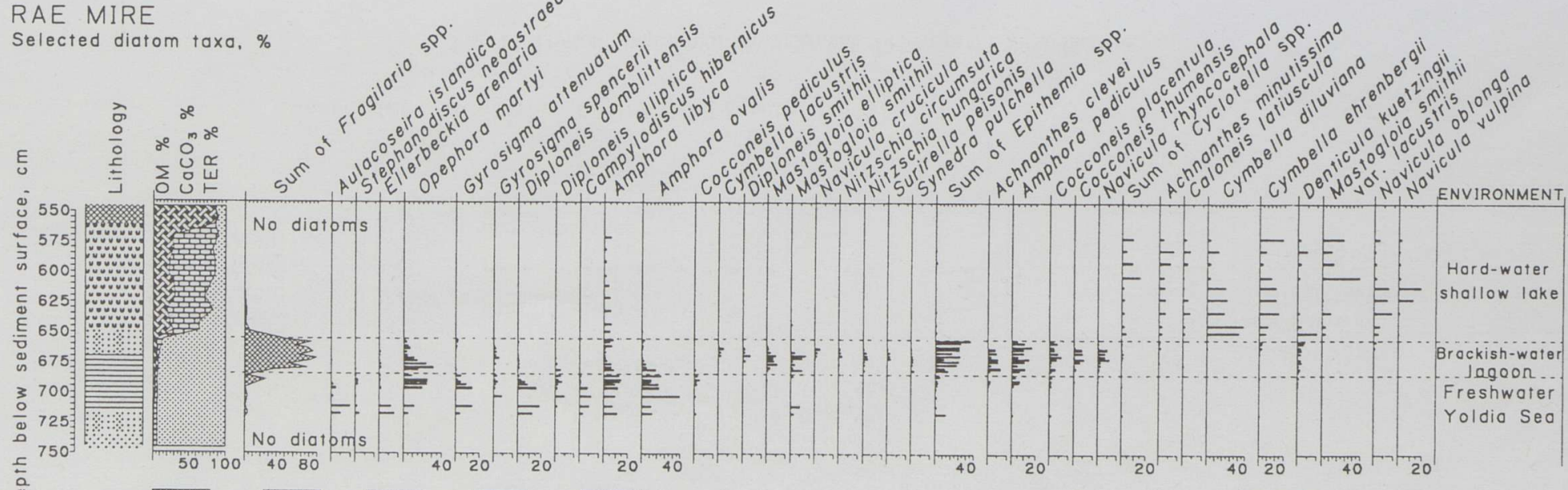




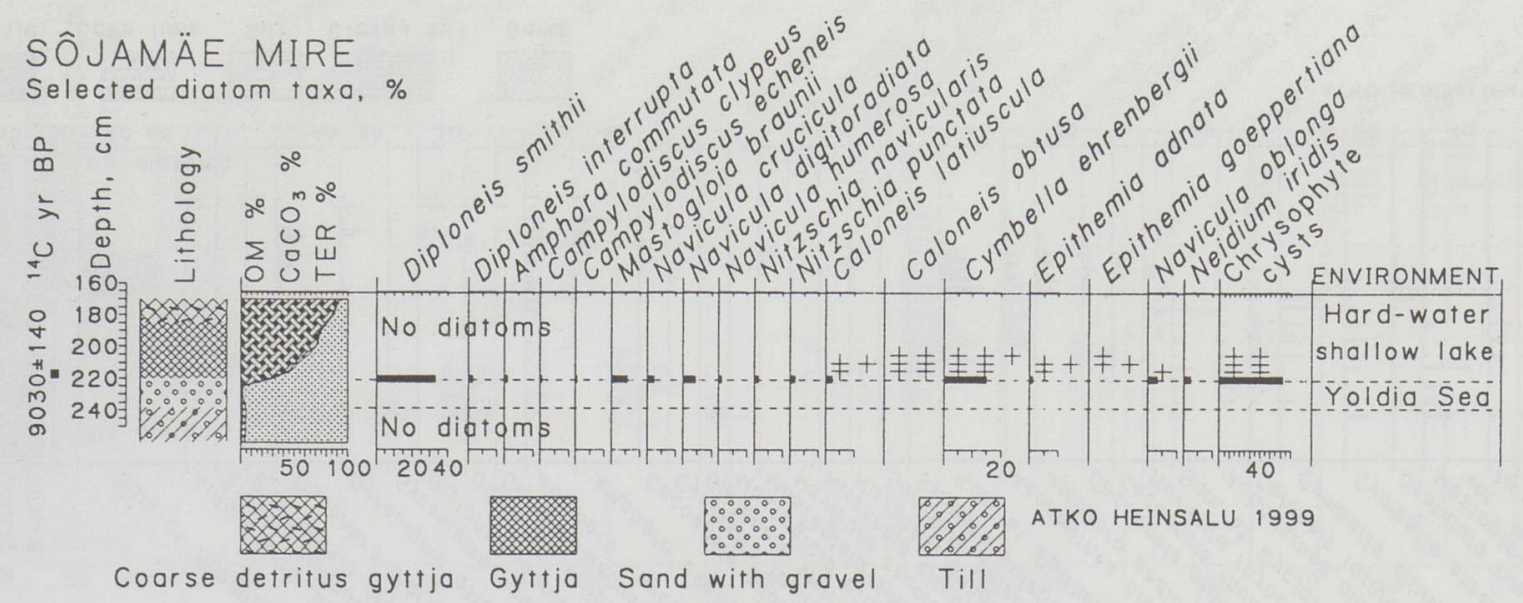

Fig. 11. Diatom diagram of the sediment core from the Sõjamäe site.

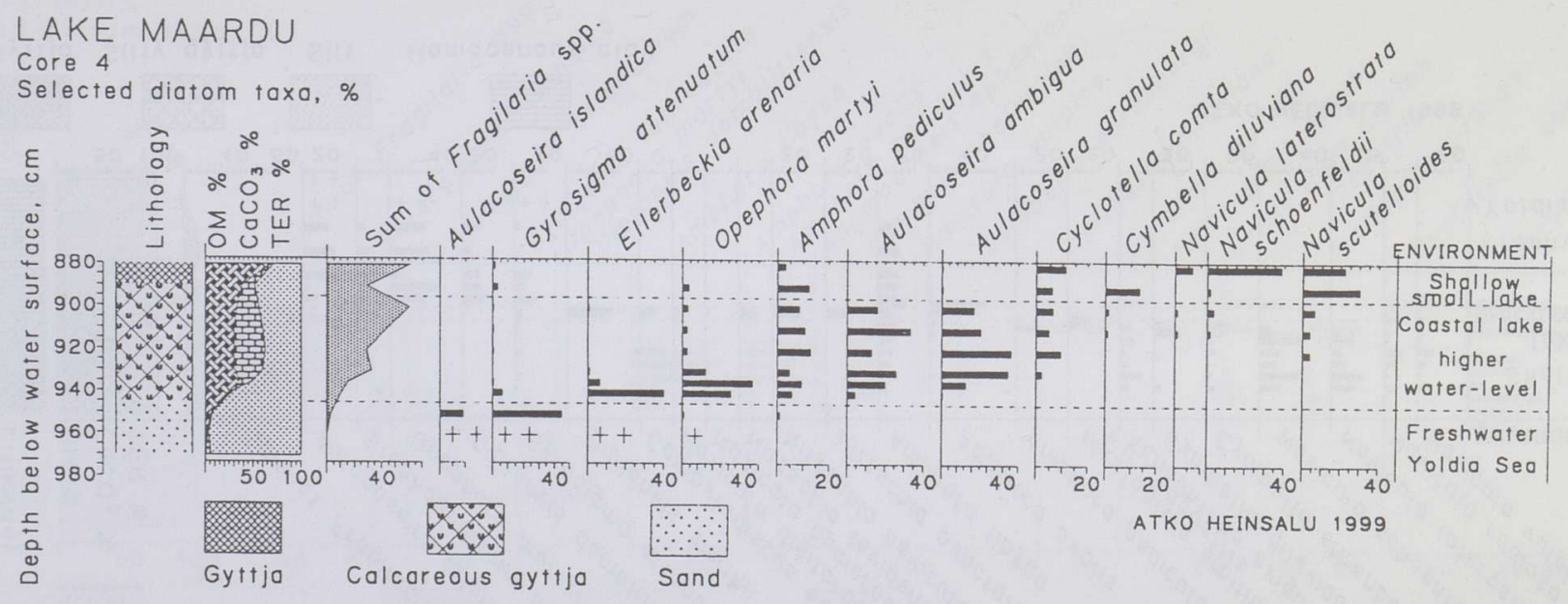

Fig. 12. Diatom diagram of the sediment core from Lake Maardu.

\section{LAKE ÜLEMISTE}

Selected diatom

taxa, \%

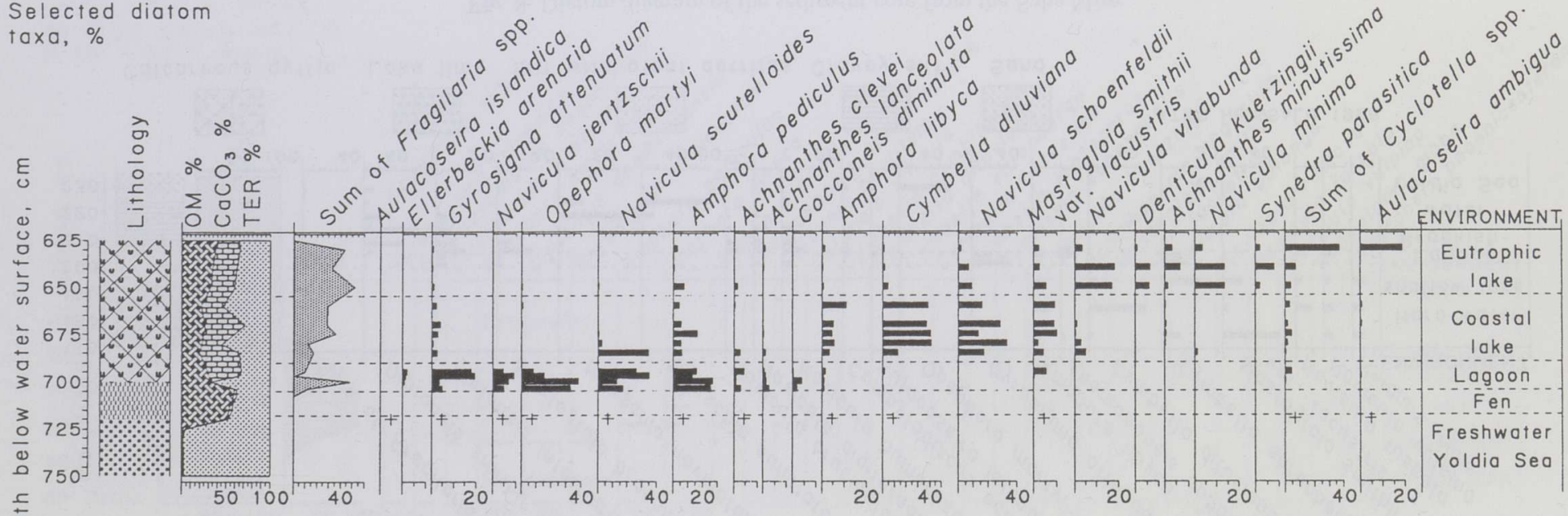

告
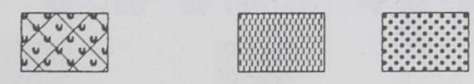

ATKO HEINSALU 1999

Calcareous gyttja Peat Sand

Fig. 13. Diatom diagram of the sediment core from Lake Ülemiste. 
silt deposited during the Pre-Boreal (Veski 1998). Large-lake diatoms, e.g. Stephanodiscus neoastraea, Ellerbeckia arenaria, Opephora martyi, Diploneis domblittensis, and Gyrosigma attenuatum predominate in the upper part of the basal sand (Fig. 7). They indicate relatively shallow water in the Vandjala basin, with a connection to the freshwater Yoldia Sea. The transition from sand to silt reflects the isolation level. High values of littoral Fragilaria spp., low numbers of some periphytic large-lake diatoms, high frequency of epipsammic diatoms and small-lake diatoms suggest the existence of a relatively large shallow coastal lake in the Vandjala basin.

Diatom analysis from the Tondi site, a previous mire in the eastern part of Tallinn (Fig. 1), was performed by M. Sakson. The initial depositional environment of the Tondi basin was explained as a shallow, slightly brackish lagoonal bay of the Yoldia Sea (Lepland et al. 1995). This conclusion was based upon the peaks of Fragilaria brevistriata and $F$. pinnata together with rather high amounts of Amphora pediculus and Anomoeoneis sphaerophora in the basal clay between 358 and $350 \mathrm{~cm}$. However, the present paper proposes an alternative interpretation to that diatom assemblage. High values of littoral Fragilaria species are common in both shallow freshwater and slightly brackish-water ecosystems (Stabell 1985; Vos \& de Wolf 1993). Fragilaria species have a wide conductivity tolerance and are not good markers of palaeosalinity changes along environmental gradients. Amphora pediculus and Anomoeoneis sphaerophora both occur in freshwater lakes with high conductivity but can also survive in the water with a lower salt ion concentration. The diatom assemblage of the Tondi sediment sequence resembles strongly the one common in shallow postisolation coastal lakes in northern Estonia; preisolation sediments seem to be lacking there at all.

The Saha Mire lies southwest of Lake Maardu (Fig. 1). Most of it is drained and used as a meadow. The threshold of the basin is to the west of the mire at an altitude of $34 \mathrm{~m}$ a.s.l. (Table 1). The pollen record from the Saha Mire shows the accumulation of clayey silt and silt during the Early Pre-Boreal (Kihno 1996). The upper part of the basal sand contains $72 \%$ large-lake diatoms and $21 \%$ brackish-water diatoms. In the clayey silt, brackish-water diatoms constitute $83-95 \%$ of the assemblage. The abundance of diatoms and the species diversity of the brackish-water taxa is relatively high; altogether 32 mesohalobous species were identified. The littoral brackish-water diatom species Diploneis smithii, D. interrupta, Nitzschia navicularis, N. punctata, and Mastogloia braunii predominate (Fig. 8). Prior to the isolation, the Saha basin was part of a shallow strait of the brackish-water Yoldia Sea. At a core-depth of $204 \mathrm{~cm}$ Fragilaria spp. increase, brackish-water diatoms decline, large-lake taxa successively increase and constitute $30-50 \%$ of the assemblage. It is likely that during the deposition of silt with plant detritus between 204-197 cm the brackish-water phase of the Yoldia Sea came to an end and a rapid freshening of the coastal areas in northern Estonia occurred. Alternatively, a coastal lagoon with a decreasing water level 
and narrowing connection with the sea formed in the Saha basin. The final isolation of the Saha basin is indicated by the spread of small-lake diatoms recorded at a core-depth of $195 \mathrm{~cm}$. According to the diatom analysis, the waters of the Ancylus Lake transgression did not ingress into the Saha basin, so the upper limit of the Ancylus Lake transgression maximum should be below $34 \mathrm{~m}$ a.s.l. in the area.

The Pääsküla Mire is situated at the southwestern border of Tallinn (Fig. 1). Its threshold lies to the west at an altitude of $34 \mathrm{~m}$ a.s.l. (Table 1). Predominant diatoms in the basal clay are the typical planktonic large-lake species Aulacoseira islandica and Stephanodiscus neoastraea and large-lake periphytic taxa, e.g. Opephora martyi, Diploneis domblittensis, and Gyrosigma attenuatum (Fig. 9), indicating rather deep and freshwater conditions in the basin. In the upper part of the clay the diatom assemblage abruptly changes to the one dominated by brackish-water taxa, such as Diploneis smithii, Nitzschia navicularis, N. punctata, and Campylodiscus echeneis. This shift in the diatom composition can be related to the event when brackish water spread into the coastal area of northern Estonia during the Yoldia Sea brackish-water phase. The isolation of the Pääsküla basin is interpreted to have taken place at the boundary between the clay and the silt, characterized by the expansion of Fragilaria spp., disappearance of brackish-water diatoms, and predominance of small-lake diatoms indicating a shallow hard-water lake.

The Rae Mire occupies a depression with a threshold to the west at an elevation of c. $37.5 \mathrm{~m}$ a.s.1. (Table 1) at the southeastern border of Tallinn (Fig. 1). The basal silts deposited in the Younger Dryas and the Pre-Boreal, and the lake lime in the Boreal (Kessel \& Punning 1969). The lower part of clayey silt contains mostly large-lake diatoms (Fig. 10). The frequency of Aulacoseira islandica decreases constantly and periphytic large-lake diatoms predominate. Thus the regression of the initial freshwater Yoldia Sea phase led to a continuous drop of the water level in the basin. A pronounced change in the fossil diatom assemblage took place at a core-depth of $685 \mathrm{~cm}$ : a sudden rise in Fragilaria spp. and the expansion of lagoonal epiphytic Epithemia species and epipsammic diatoms together with an increase in both the number of species and the abundance of littoral brackish-water diatoms. The commonest diatom species recorded are the slightly brackish-water taxa, e.g. Cocconeis pediculus, Mastogloia smithii, M. elliptica, Cymbella lacustris, Diploneis smithii, Nitzschia circumsuta, $N$. hungarica, and Navicula crucicula. A sheltered lagoon, which was connected with the Yoldia Sea by shallow straits in the west and east, developed in the Rae basin when salt water spread along the coast of northern Estonia. That explains the lower share and salt tolerance of brackish-water diatoms in the Rae sediment sequence compared with the Saha and Pääsküla basins. The final isolation of the Rae basin is recorded in the transition between the silt and the lake lime and is characterized by the predominance of a shallow hard-water lake diatom assemblage. 
The Sõjamäe site is a previous mire which is nowadays covered with a waste dump. The Sõjamäe basin lies in the eastern part of Tallinn (Fig. 1) and occupies a depression with a southward orientated threshold at an elevation of $37.8 \mathrm{~m}$ (Lepland et al. 1995). According to pollen analysis, the basal gyttja between 442 and $428 \mathrm{~cm}$ accumulated during the Pre-Boreal (Kessel 1961b) and was dated to $8915 \pm 90{ }^{14} \mathrm{C}$ years BP (Tln-135; Punning et al. 1977). Sõjamäe was the first site where the Pre-Boreal brackish-water diatoms were recognized. Diatom analyses were performed by M. Pork. Her original slides and counting lists are deposited in the Limnological Station at Lake Võrtsjärv. The diatoms found on the slides are poorly preserved. Altogether, 35 diatom taxa were identified by M. Pork from the lowermost gyttja sample (No. 39) at a core-depth of $440 \mathrm{~cm}$. Of those, mesohalobous Navicula peregrina, Amphora coffeaformis, and Synedra pulchella, as well as salinity indifferent Mastogloia smithii and M. smithii var. amphicephala are widespread in the present Baltic Sea (Snoeijs 1993; Snoeijs \& Vilbaste 1994; Snoeijs \& Potapova 1995). The other diatoms encountered were small-lake taxa. In the gyttja between 438 and $434 \mathrm{~cm}$ (samples 38 and 37) a single specimen of the halophilous diatom (i.e. a freshwater form stimulated by low salt concentration) Rhoicosphenia curvata and mesohalobous Amphiprora paludosa were found together with freshwater diatoms. However, it is inaccurate to reconstruct the palaeoenvironment of the Sõjamäe basin on the basis of few diatom specimens.

In the northern part of the Sõjamäe basin a sediment sequence, analogous to the previously studied section, was reinvestigated. The basal till, gravel, and sand are overlain by gyttja (Fig. 11). The sharp boundary between the sand and the gyttja suggests a hiatus in sedimentation which is supported by the date $9030 \pm 140{ }^{14} \mathrm{C}$ years BP (Tln-2346) from the lowermost $5 \mathrm{~cm}$ of the gyttja. According to the threshold altitude, the Sõjamäe basin isolated from the Yoldia Sea in the Early Pre-Boreal. Diatoms were poorly preserved in the Sõjamäe sediment sequence and mostly diatoms typical of shallow hard-water lakes, e.g. Caloneis obtusa, C. latiuscula, Cymbella ehrenbergii, and Navicula oblonga, occurred. At the lower surface of the gyttja, brackish-water diatoms similar to those from the Saha and Pääsküla sediment records were observed. Probably these diatoms derive from the preisolation Yoldia Sea sediments which are missing in the studied sequence. It is possible that after the isolation, and as a consequence of the Yoldia Sea regression, the water level in the Sõjamäe basin sank and/or the lake even dried up. The water level rose again at the end of the Late Pre-Boreal when the climate became more humid in coastal areas, probably due to the Ancylus Lake transgression.

Lake Maardu is situated at the eastern border of Tallinn (Fig. 1) in the depression of an ancient klint bay (Saarse et al. 1996a). The threshold of the Maardu basin was at $32 \mathrm{~m}$ a.s.l. during the Yoldia Sea (Saarse et al. 1997). Several sediment cores have been investigated from Lake Maardu (Saarse et al. 1996b). The location of the cores and the study results are summarized in Veski 
(1998). A thin layer of peat overlying the sand was found in the western part of the Maardu basin at an altitude of 25-24 m a.s.l., indicating that the Maardu depression emerged from the sea during the final freshwater phase of the Yoldia Sea. The upper part of the sand contains large-lake diatoms Aulacoseira islandica, Gyrosigma attenuatum, and Opephora martyi (Fig. 12). There is probably a hiatus between the sand and the calcareous gyttja. A piece of wood was found at the contact of the mineral bottom and gyttja in the central part of the lake, which was dated to $9490 \pm 110{ }^{14} \mathrm{C}$ years BP (Ua-2390) by the AMS technique. Pollen data show that the lower part of the calcareous gyttja accumulated during the Late Pre-Boreal (Veski 1998). The deposits are characterized by high values of Aulacoseira ambigua and $A$. granulata. These planktonic diatoms are common in relatively deep eutrophic lakes. Periphytic diatoms Ellerbeckia arenaria and Opephora martyi favouring a sandy littoral bottom show a distinct successive decrease. The diatom stratigraphy reflects an increase in water depth of the basin. A rise of the water level can be associated with the Ancylus Lake transgression which dammed up the lake, but probably the waters of the Ancylus Lake itself did not flood into the Maardu basin. Additionally, the diatom assemblage from the basal silty gyttja in the central part of the lake does not suggest a connection of the basin with the Ancylus Lake (Sakson 1996). The immediate decline in small-lake planktonic diatoms and the expansion of periphytic diatoms at a depth of $900 \mathrm{~cm}$ can be explained by a sudden drop of the water level in the Maardu basin. Pollen analysis from the same core places this event to the transition from the Late Pre-Boreal to the Early Boreal (Veski 1998). Consequently, the rapid decrease in the water level, indicated by the disappearance of planktonic diatoms, marks the end of the Ancylus Lake transgression and the succeeding regression, which presumably occurred at c. $9000{ }^{14} \mathrm{C}$ years BP in northern Estonia.

Lake Ülemiste is situated in the southeastern part of Tallinn (Fig. 1). Its basin is filled with sand, peat, calcareous gyttja, and gyttja. The primary Pre-Boreal threshold of the lake is situated north of the lake at an altitude of $31.5 \mathrm{~m}$ a.s.l. (Table 1). The accumulation of the basal peat in the Ülemiste basin started at an altitude of $25.5 \mathrm{~m}$ a.s.l. at c. $9500{ }^{14} \mathrm{C}$ years $\mathrm{BP}$, and the upper part of the peat originates from c. $9200{ }^{14} \mathrm{C}$ years BP (Saarse et al. 1997). The peat formed during the final phase of the Yoldia Sea, when the sea level had regressed approximately to an altitude of $25 \mathrm{~m}$ a.s.1. Reconstruction of the preisolation environment at the Ülemiste basin is complicated, as the abundance of diatoms in the basal sand is too low. Single valves of large-lake diatoms and some small-lake specimens were encountered. The sediment record formerly investigated from Lake Ülemiste contains up to $10 \%$ Aulacoseira islandica in the lower part of the peaty gyttja overlying the sand (Saarse et al. 1997). As most of these diatoms were broken, it is possible that they originate from the preisolation sediments, and consequently show a freshwater environment of the Yoldia Sea prior to the isolation. In the upper part of the peat and lower part of the calcareous gyttja periphytic large-lake 
diatoms, e.g. Gyrosigma attenuatum, Navicula jentzschii, and Opephora martyi, occur together with epipsammic diatoms, such as Amphora pediculus, Achnanthes lanceolata, A. clevei, and Cocconeis diminuta (Fig. 13). The Ancylus Lake transgression led to the water level rise in the Ülemiste basin and probably a brief connection to the Ancylus Lake existed during the transgression maximum. Otherwise a vast shallow coastal lake or lagoon developed in the Ülemiste basin. Small-lake diatoms, e.g. Navicula schoenfeldii, Cymbella diluviana, and Mastogloia smithii var. lacustris, predominate in the calcareous gyttja between 690 and $640 \mathrm{~cm}$, indicating a shallow eutrophic lake environment. At a coredepth of $630 \mathrm{~cm}$ and upward the planktonic diatom Aulacoseira ambigua appears and distinctly increases in abundance. A similar trend was recorded in the Late Boreal sediments in Lake Kahala, and probably this is consistent with a rise of the water level in these lakes.

Chrysophyte cysts. Chrysophyceae are a diverse group of algae, which are commonly planktonic but occasionally benthic, and are components of algal assemblages from many different types of water bodies (Duff et al. 1995). A characteristic feature of chrysophytes is their ability to produce resting stages in the form of endogenously formed siliceous cysts, which are well preserved in sediments (Cronberg 1986). Because the chrysophytes are presumed to have restricted environmental requirements, their importance as palaeolimnological indicators has risen in the last decades (Smol 1988). The information obtained from chrysophyte records has been applied to the reconstruction of the past trophic state of the lakes, $\mathrm{pH}$, salinity, and conductivity of the water, and other limnological variables, as well as climate (Smol 1995).

Chrysophyte cysts are often abundant in postisolation sediment records in northern Estonia (Figs. 2, 11; Appendix, Figs. A6, A7). In the sequences figured fragmentation and/or dissolution of diatoms are also observed. In those sequences, diatoms with more heavily silicified morphology are overrepresented in fossil assemblages, as robust species most likely better resist dissolution and/or mechanical fragmentation, which has led to their preferential enrichment (Fig. 2; Appendix, Figs. A4, A5). Chrysophyte cysts seem to be more resistant to dissolution and mechanical breakage than diatoms and are similarly relatively enriched. Thus, a high abundance of chrysophyte cysts in the sediment can also be related to the degree of dissolution of fossil diatom assemblages in sediments.

Redeposited diatoms. The brackish-water phase of the Yoldia Sea in the Baltic Sea proper is defined by a high abundance of the planktonic brackish-water diatom Thalassiosira baltica (e.g. Lepland et al. 1999; Andrén et al. 2000). Thalassiosira baltica is a very common species in the photic zone of the present Baltic Sea, where salinity ranges between 3\%o and 10\%o (Snoeijs 1993). Ostracods and foraminifera found in the Yoldia Sea sequences from the northwestern Baltic Sea and from eastern central Sweden suggest cold bottom water with a salinity from $3 \%$ to $15 \%$ (Wastegård 1996). The brackish-water diatom records from the Saha, Pääsküla, and Rae mires demonstrate an intrusion 
of a salt-water pulse into the northern coast of Estonia during the Yoldia Sea. Since the existence of a connection between the Baltic Sea and the White Sea basins during the late-glacial has been proved impossible (Saarnisto et al. 1995), it is unlikely that the salinity of the Gulf of Finland during the brackish-water intrusion was higher than in the western Baltic basin. The saline water penetrated into the Gulf of Finland from the west, most probably along the bottom.

The basal preisolation clay and silt-bearing parts of the sequences studied (Figs. 3-5) can contain mixed with large-lake diatoms, single valves of marine diatoms with salt concentration optima higher than $10 \%$. Polyhalobous Stephanopyxis turris, Thalassiosira eccentrica, Chaetoceros mitra, and Grammatophora marina, mesohalobous Hyalodiscus scoticus, Paralia sulcata, Rhabdonema arcuatum, and $R$. minutulum are related to that diatom assemblage. Pieces of unidentified large marine centric diatoms and silicoflagellates are also observed. These marine diatoms are not evenly distributed through the sediment sequence; they are encountered when the diatom abundance in sediments is very small and are not recorded when the diatom bioproductivity has increased. Taking into consideration the palaeosalinity records of the Yoldia Sea close to the inflow area in Sweden, these marine diatoms should have derived from an environment with a much higher salt concentration and thus are interpreted as being redeposited. The Eemian Baltic Sea had a clearly higher salinity than the modern Baltic Sea and the above-mentioned diatom taxa are common in the deposits of the last interglacial (Grönlund 1991). The frustules of robust marine species with a high degree of silification appear to have been more resistant to abrasion and dissolution and hence possess better preservation potential (Miller \& Persson 1973).

\section{SHORELINE DISPLACEMENT}

In northern Estonia the shoreline displacement has been regressive throughout the Yoldia Sea due to intensive land uplift (Fig. 14). The coastal formations of the Yoldia Sea are fragmented and scattered, which makes their correlation impossible. The coastal formations of the final phase of the Yoldia Sea have been destroyed by the Ancylus Lake transgression. Therefore the reconstruction of the shore displacement curve in this study is based on the threshold altitudes of isolated basins. During the Younger Dryas - Pre-Boreal transition the rate of land uplift was c. $3 \mathrm{~cm} /$ year around Tallinn (Kessel \& Miidel 1973). The maximal direction of tilting was $146^{\circ}$ during the Baltic Ice Lake, the Yoldia Sea, and the Ancylus Lake (Kessel \& Miidel 1973). Isobases are running from northeast to southwest in northern Estonia. The earth's crust has emerged a little bit faster in the west than in the east. Therefore the threshold altitudes of the investigated sites were corrected according to land uplift. Isolation altitudes of the basins were projected on to the isobase passing through the thresholds of the Sõjamäe and 


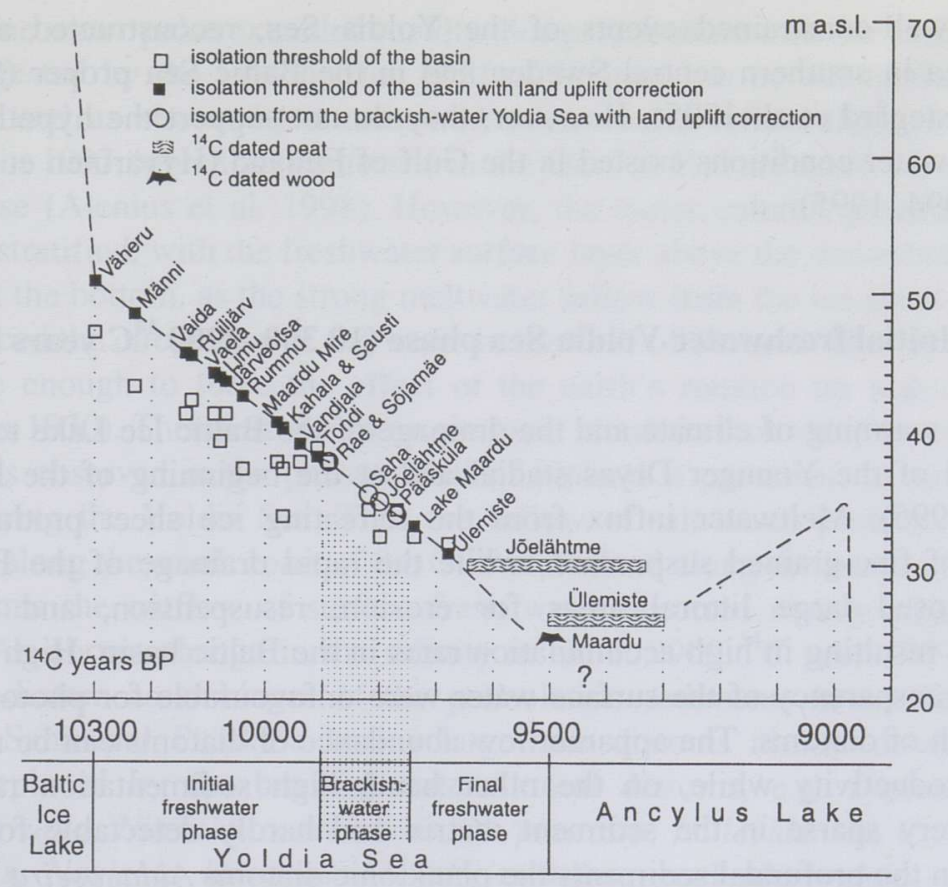

Fig. 14. The shoreline displacement curve for the investigated area. The altitudes of the basin isolation thresholds are given with and without the correction of land uplift.

the Rae basin at an altitude of $37.5 \mathrm{~m}$ a.s.l. (Fig. 1). The gradient of the shorelines was estimated at c. $37 \mathrm{~cm} / \mathrm{km}$. The interpolated shore level prior to the final drainage of the Baltic Ice Lake on the Sõjamäe-Rae isobase was approximately at 75 m a.s.l. (Kessel 1961a). During the drainage of the Baltic Ice Lake the water level dropped c. $25 \mathrm{~m}$, to the level of c. $50 \mathrm{~m}$ a.s.l. (Fig. 14). In Lake Maardu a peat layer at an altitude of $25-24 \mathrm{~m}$ a.s.l. and with the age of c. $9500{ }^{14} \mathrm{C}$ years BP indicates the regression of the shoreline of at least $25 \mathrm{~m}$ in the study area during the Yoldia Sea.

\section{PALAEOENVIRONMENT OF THE YOLDIA SEA}

The diatom stratigraphic changes of 20 different isolation basins were used for the reconstruction of the palaeoenvironment in northern Estonia during the Yoldia Sea. According to the results of the present study, the history of the Yoldia Sea on the south coast of the Gulf of Finland can be divided into three phases. The initial and the final phase were characterized by a freshwater environment. Brackish-water conditions, however, prevailed during a short period of time in between. The results of new diatom studies presented here correlate 
with the well-constrained events of the Yoldia Sea, reconstructed along the inflow area in southern central Sweden and in the Baltic Sea proper (Svensson 1989; Wastegård et al. 1995). However, they do not support the hypothesis that only freshwater conditions existed in the Gulf of Finland (Hyvärinen et al. 1992; Raukas 1994, 1995).

\section{The initial freshwater Yoldia Sea phase $\left(10300-9900{ }^{14} \mathrm{C}\right.$ years BP)}

Global warming of climate and the drainage of the Baltic Ice Lake took place at the end of the Younger Dryas stadial and at the beginning of the Holocene (Björck 1995). Meltwater influx from the retreating ice sheet produced vast amounts of fine-grained suspension, while the rapid drainage of the Baltic Ice Lake exposed large littoral areas for erosion, resuspension, and transport processes, resulting in high accumulation rates in the Baltic basin. High turbidity and low transparency of the surface water were unfavourable for photosynthesis and growth of diatoms. The apparent low abundance of diatoms can be related to low bioproductivity while, on the other hand, high sedimentation rate made diatoms very sparse in the sediment matrix and hardly detectable for diatom analysis. In the profundal sediments the planktonic diatoms Aulacoseira islandica and Stephanodiscus neoastraea predominate, indicating that the surface waters along the northern coast of Estonia were still occupied by fresh water. Low illuminance inhibited the growth of periphytic diatoms; these derived from the nearshore areas, while single marine valves were reworked from the older deposits. Prior to the isolation of the studied basins, in very shallow littoral areas where light penetrated to the bottom, bioproduction was more intensive. Periphytic large-lake diatoms, such as Gyrosigma attenuatum, G. acuminatum, G. spencerii, Diploneis domblittensis, Opephora martyi, Ellerbeckia arenaria, Epithemia frickei, Amphora ovalis, and A. libyca, were common.

\section{The brackish-water Yoldia Sea phase $\left(9900-9750{ }^{14} \mathrm{C}\right.$ years BP)}

Björck et al. (1996, 1997) suggest that the occurrence of the Early Pre-Boreal climatic cooling between $10000-9900$ and $9600-9500{ }^{14} \mathrm{C}$ years BP plateaux decreased the glacial meltwater influx from the Scandinavian Ice Sheet and could have allowed salt water to penetrate through the narrow straits in southern central Sweden into the Baltic basin. The saline bottom-water current entered the Baltic basin shortly after the straits at Närke in southern central Sweden had been deglaciated (Wastegård et al. 1998). A highly stratified water column, with brackish water at the bottom and turbid fresh water at the surface, was recorded in the Landsort Deep close to the inflow area prior to the Yoldia Sea phase with greater vertical mixing and higher surface salinity (Lepland et al. 1999). Probably 
the saline water pulse extended rapidly along the bottom into the Gulf of Finland, as suggested by the fact that the Gulf of Finland has no sill to the Baltic Sea proper, and as shown by a measured saline water inflow through the Danish Straits in 1993, which was detected in the Gulf of Finland some 18 months after the pulse (Alenius et al. 1998). However, the water column probably remained highly stratified, with the freshwater surface layer above the dense brackish-water layer at the bottom, as the strong meltwater inflow from the ice sheet in the north influenced the circulation of the water in the Gulf of Finland. The Gulf of Finland is large enough to force the effect of the earth's rotation on water circulation (Palmén 1930). Therefore the mean cyclonic (counterclockwise) water circulation which is observed in the present Gulf of Finland is presumed to have prevailed also during the Yoldia Sea. Thus the inflow of salt water probably took place mainly along the south coast of the Gulf of Finland along the bottom, while at the same time the outflow of surface fresh water occurred mostly along the north coast. An abrupt change in the salinity at about $9900{ }^{14} \mathrm{C}$ years BP is recorded by the diatom assemblages of the preisolation sediments in northern Estonia. In the Saha and Pääsküla basins large-lake diatoms almost disappeared and were replaced by the brackish-water littoral diatoms, e.g. Diploneis smithii, D. interrupta, Nitzschia navicularis, N. punctata, N. levidensis, Campylodiscus echeneis, Navicula humerosa, $N$. digitoradiata, and Mastogloia smithii. The abundance of diatoms is relatively high, which precludes their interpretation as possibly redeposited from the marine interglacial deposits. The brackish-water phase has been estimated to last c. $150{ }^{14} \mathrm{C}$ years (Fig. 14) and is synchronized with the start and duration of the brackish-water phase of the Yoldia Sea in the inflow area (Svensson 1991; Andrén et al. 1999). The spread of brackish water into the coastal areas was probably triggered by upwelling, which is the most important process causing vertical mixing near coastal areas and is rather common in the Baltic Sea today (Bychkova \& Viktorov 1987; Gidhagen 1987; Haapala 1994). Near the north coast of Estonia easterly longshore winds of long duration are needed to generate upwelling (Hela 1976). It is likely that during the middle phase of the Yoldia Sea strong winds blowing opposite to the main current flow carried surface water away and it was replaced by saline water from below the halocline. According to the diatom assemblages, the salinity at the north coast of Estonia was not higher than in the present Gulf of Finland.

\section{The final freshwater Yoldia Sea phase $\left(9750-9500{ }^{14} \mathrm{C}\right.$ years BP)}

The end of the Pre-Boreal cooling event and the following rapid warming of the climate increased meltwater flux from the ice sheet and the outflow through the Swedish straits, thus hampering the penetration of salt water from the ocean to the Baltic basin. The thickness of the saline bottom water layer in the Gulf of Finland therefore decreased, the halocline dropped down, and consequently 
upwelling was not generated any more. As a result, rapid freshening of coastal waters probably occurred in northern Estonia. Diatoms from the preisolation sediments of lakes Ülemiste and Maardu indicate a large-lake environment during the final phase of the Yoldia Sea (Fig. 14). Diatoms are not well preserved in these sediment records, therefore it is difficult to estimate the productivity during this phase. Absolute abundance of diatoms, however, shows low productivity values during the final freshwater phase of the Yoldia Sea for cores from the Baltic Sea proper (Abelmann 1985; Andrén et al. 2000).

\section{ACKNOWLEDGEMENTS}

The investigation has been supported by the Nessling Foundation. Dr. Siim Veski assisted in field work, Ms. Sirje Hiie identified macrofossils, Prof. Michel Bouchard revised the English language, Prof. Urve Miller and Dr. Reet Laugaste read the manuscript and made valuable comments.

APPENDIX

\section{DIATOM STRATIGRAPHY OF SEVEN SITES IN NORTHERN ESTONIA}

Lake Väheru is located in the southern part of the area (Fig. 1) and is surrounded by a mire (referred to as the Vaharu Mire) with an area of 1200 ha. According to the threshold altitude (Table 1), the Väheru basin is the oldest among the investigated sites. The history of vegetation around the Vaharu Mire was studied by means of pollen analysis and ${ }^{14} \mathrm{C}$ dating by Sarv \& Ilves (1971). The silt and the lowermost part of the lake lime were interpreted as accumulated during the Pre-Boreal. The date $10290 \pm 130{ }^{14} \mathrm{C}$ years BP (Tln-174) from the lake lime gave an age older than expected. Diatoms are poorly preserved in the sediments of Lake Väheru; only central areas of some valves are observed. There were no diatoms indicating preisolation environmental conditions in the basin. The calcareous silts contain a few diatoms typical of a hard-water small lake, such as Mastogloia smithii var. lacustris, Caloneis latiuscula, and C. obtusa (Fig. A1). The lack of marginal areolae makes it impossible to identify the valves of the genus Cyclotella to the species level; the eroded central areas probably belong to $C$. distinguenda and to the former $C$. kuetzingiana complex. The $\mathrm{CaCO}_{3}$ content of the silt possibly originates from clastic input to the lake from the calcareous tills surrounding the basin.

The isolation threshold of the Vaida Mire (Fig. 1) basin lies in the valley of the Pirita River, northwestward of the basin. Prior to the isolation, in the silty sands and silts, a large-lake diatom assemblage was found (Fig. A2). The isolation from the Yoldia Sea took place during the freshwater environment. The 


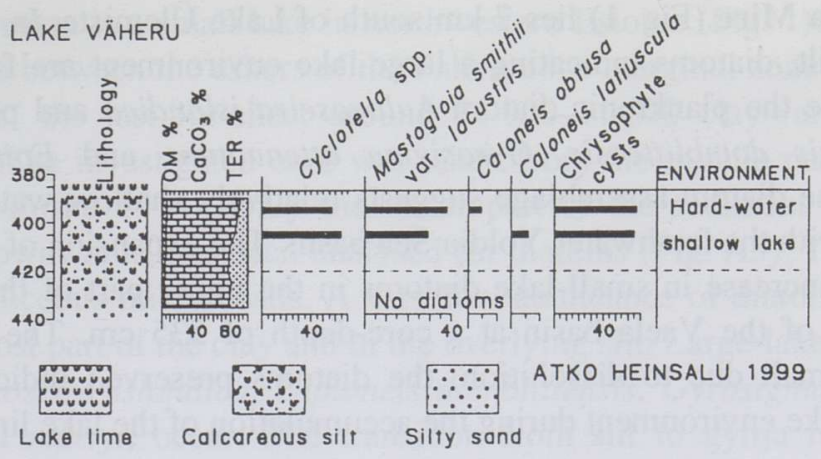

Fig. A1. Diatom diagram of the sediment core from Lake Väheru.

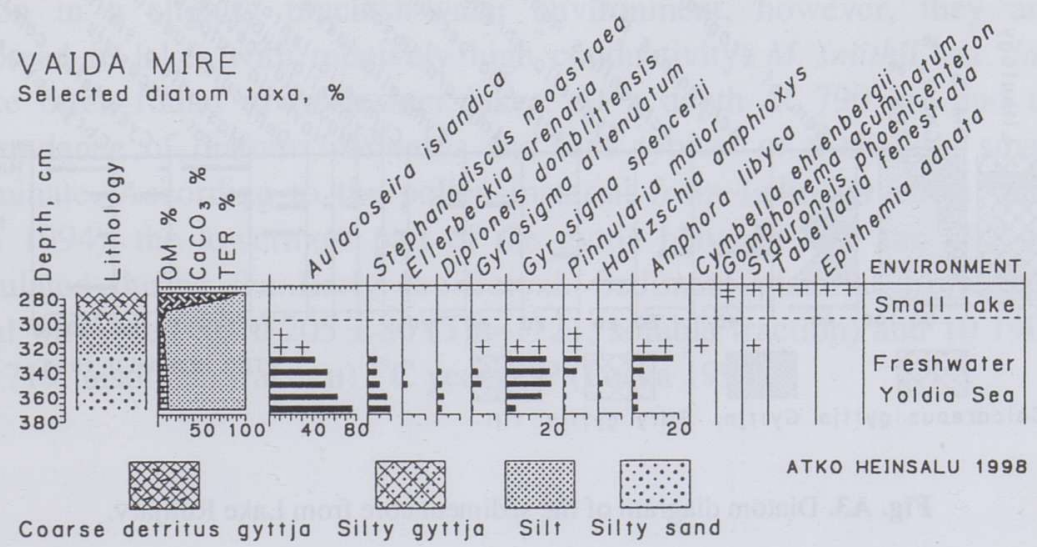

Fig. A2. Diatom diagram of the sediment core from the Vaida Mire.

abundance of diatoms is low, with planktonic Aulacoseira islandica and Stephanodiscus neoastraea dominating. The diatoms are mostly dissolved in the upper part of the sequence, therefore it is difficult to determine the exact isolation level in the sediment. However, according to the lithology, increased values of loss-on-ignition, and the presence of single small-lake diatoms, it falls into the silty gyttja.

Lake Ruiljärv is a small lake with the surface area of 16 ha, situated west of Lake Väheru (Fig. 1). The silty gyttja bed overlying the basal till contains small-lake diatoms (Fig. A3). The calcareous gyttja is characterized by a shallow hard-water lake diatom assemblage. Preisolation sediments were not recognized, therefore, either sedimentation has not occurred during the Yoldia Sea or the basin has been influenced by wave action, with erosion of the existing sediments. 
The Vaela Mire (Fig. 1) lies $7 \mathrm{~km}$ south of Lake Ülemiste. In the lowermost part of the silt, diatoms indicating a large-lake environment are fairly common. These include the planktonic diatom Aulacoseira islandica and periphytic taxa, e.g. Diploneis domblittensis, Gyrosigma attenuatum, and Epithemia frickei (Fig. A4). The diatom assemblage suggests relatively shallow water and a weak connection with the freshwater Yoldia Sea basin. The expansion of the Fragilaria spp. and an increase in small-lake diatoms in the upper part of the silt supports the isolation of the Vaela basin at a core-depth of $535 \mathrm{~cm}$. The abundance of diatoms is small due to dissolution; the diatoms preserved indicate a shallow hard-water lake environment during the accumulation of the lake lime.

LAKE RUILJÄRV

Selected diatom taxa, \%

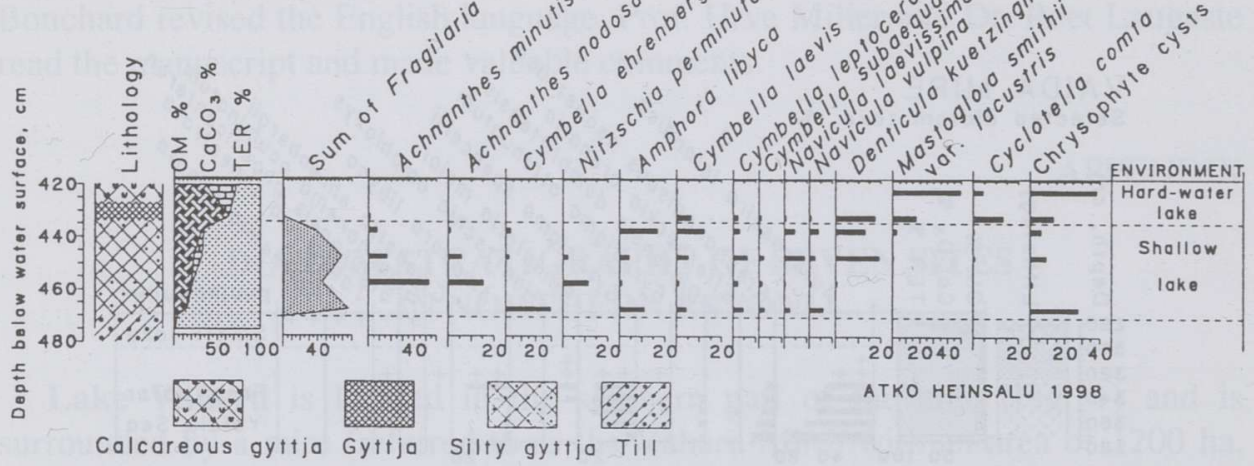

Fig. A3. Diatom diagram of the sediment core from Lake Ruiljärv.

VAELA MIRE

Selected diotom taxo, \%

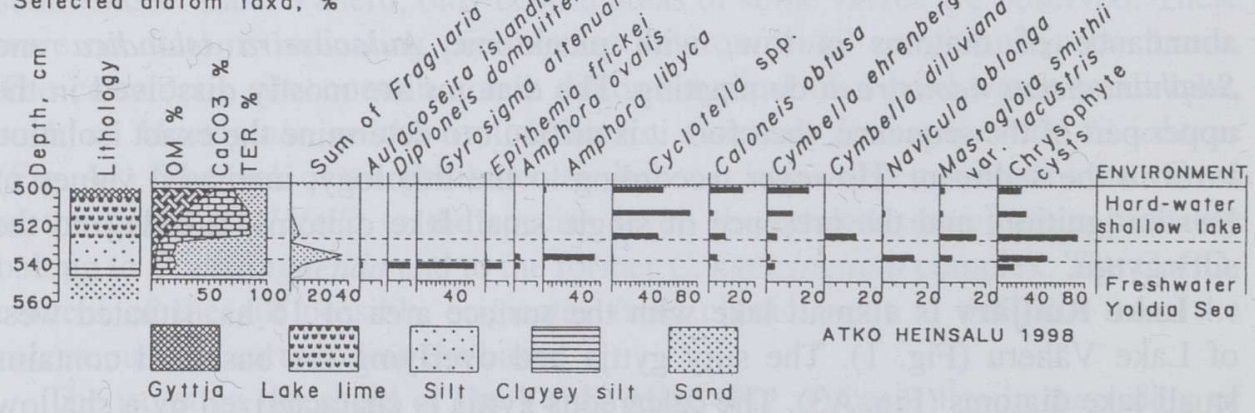

Fig. A4. Diatom diagram of the sediment core from the Vaela Mire. 
Lake Järveotsa is a small lake in northwestern Estonia (Fig. 1). It is situated in a depression between the eskers of the Palivere ice-marginal zone which marks the position of the last ice-sheet around 11900-11800 clay-varve years BP (Hang 1997). The investigated core was taken from the middle part of the lake (see fig. 9 in Poska 1994). Only the lower part of the sediment profile, from $778 \mathrm{~cm}$ and downwards, has been analysed for diatoms (Fig. A5). The basal clay is barren of siliceous microfossils. A very low abundance of diatoms was found in the uppermost part of the clay and in the overlying silt. Large-lake diatom taxa, such as Aulacoseira islandica, Diploneis domblittensis, Gyrosigma attenuatum, and Opephora martyi, occur. The transition from silt to gyttja represents the isolation level. The abundance of diatoms is still low and dissolution of diatoms is quite obvious. Large-lake diatom species decline and are replaced by smalllake species. Mastogloia smithii, M. smithii var. lacustris, M. elliptica, and Cyclotella spp. are most common. Mastogloia smithii and M. elliptica are common in a slightly brackish-water environment, however, they are also widespread in lakes with relatively high conductivity. M. smithii var. lacustris is more often found in freshwater lakes. At a depth of $790 \mathrm{~cm}$ and upward the abundance of diatoms increases and taxa typical of a shallow small lake predominate. According to the pollen material from Lake Järveotsa sediments (Poska 1994), the lowermost part of the gyttja between 803 and $793 \mathrm{~cm}$ was accumulated during the Early Pre-Boreal. Sediment material from the same interval was dated to $10205 \pm 80$ (Tln-1721; soluble fraction) and $10190 \pm 110$ (Tln-1719; insoluble fraction) ${ }^{14} \mathrm{C}$ years BP (Poska 1994).

LAKE JÄRVEOTSA

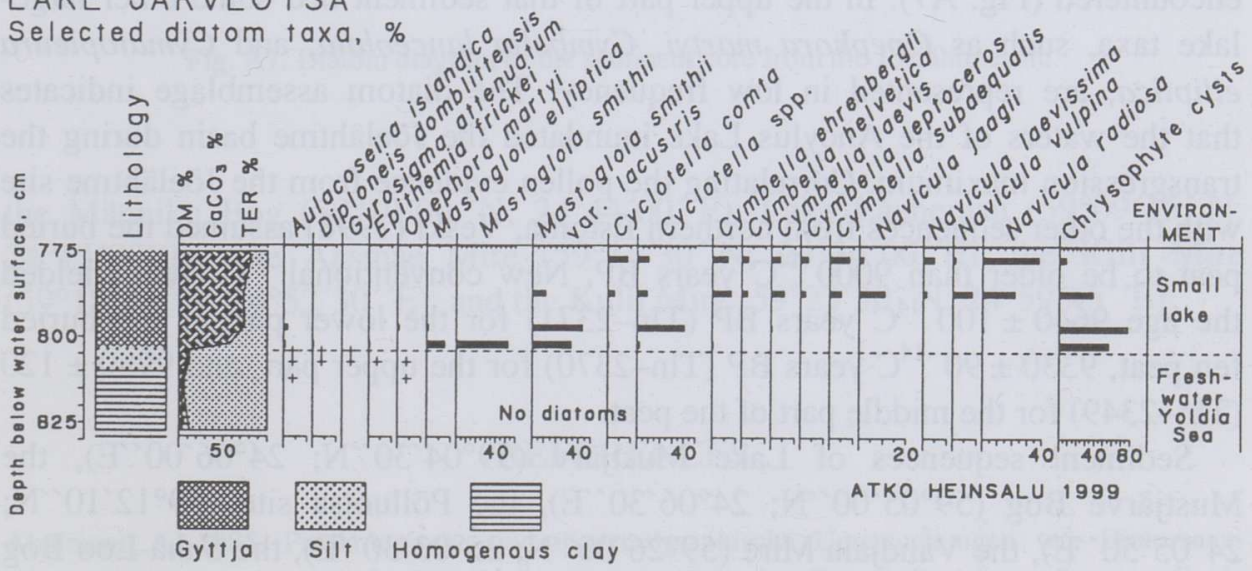

Fig. A5. Diatom diagram of the sediment core from Lake Järveotsa. 
The Maardu Mire lies southeast of Lake Maardu (Fig. 1). Most of the mire has been cultivated during the recent decades. The threshold of the basin is situated to the east and coincides with the southern threshold of the Vandjala basin. The sediment sequence is almost sterile of diatoms. In the basal silt single valves of Gyrosigma attenuatum and Ellerbeckia arenaria (Fig. A6), the species characteristic of large lakes, occur. E. arenaria favours littoral areas, sandy bottom in particular. The diatom abundance is still too low at a core-depth of $255 \mathrm{~cm}$ and upwards to allow an accurate conclusion about the isolation level. Still, such small-lake diatoms as Caloneis obtusa, C. latiuscula, and Cymbella ehrenbergii which are common in shallow hard-water lakes suggest the isolation of the basin in between the transition from silt to calcareous gyttja.

The Jõelähtme site (Fig. 1) is a previous mire which has been drained and is cultivated as a meadow. The threshold of the Jõelähtme basin lies to the southeast and is estimated at c. $32 \mathrm{~m}$ a.s.l. (Table 1). The transgressional spit of the Ancylus Lake borders the Jõelähtme basin in the north. The bog and lake sediments are underlain by a 5-20 cm thick layer of fen peat (Kessel \& Raukas 1967). According to pollen data and radiocarbon dates $8745 \pm 75$ (TA-265) and $8440 \pm 70{ }^{14} \mathrm{C}$ years BP (TA-263), the accumulation of the peat took place in the Early Boreal (Kessel \& Punning 1974).

In the light of new investigations, the peat formation took place during the Yoldia Sea regression, when due to fast land uplift extensive land areas emerged from the sea. No diatoms were found in the basal sandy silts, therefore it is not possible to supply any environmental information about the salinity of the Yoldia Sea. Diatoms are corroded and/or dissolved in the silty coarse detritus gyttja overlying the fen peat. However, single preserved large-lake diatoms, e.g. Aulacoseira islandica, Ellerbeckia arenaria, and Gyrosigma attenuatum, were encountered (Fig. A7). In the upper part of that sediment bed some other largelake taxa, such as Opephora martyi, Cymbella lanceolata, and Cymatopleura elliptica, are represented in low frequency. The diatom assemblage indicates that the waters of the Ancylus Lake inundated the Jõelähtme basin during the transgression maximum. Correlating the pollen evidence from the Jõelähtme site with the other sequences from northern Estonia, Veski (1998) assumed the buried peat to be older than $9000{ }^{14} \mathrm{C}$ years BP. New conventional ${ }^{14} \mathrm{C}$ dates yielded the age $9640 \pm 100{ }^{14} \mathrm{C}$ years BP (Tln-2371) for the lower part of the buried fen peat, $9330 \pm 90{ }^{14} \mathrm{C}$ years BP (Tln-2370) for the upper part, and $9980 \pm 120$ (Tln-2349) for the middle part of the peat.

Sediment sequences of Lake Mustjärv $\left(59^{\circ} 04^{\prime} 30^{\prime} \mathrm{N} ; 2^{\circ} 06^{\prime} 00^{\prime \prime} \mathrm{E}\right)$, the Mustjärve Bog $\left(59^{\circ} 05^{\prime} 00^{\prime \prime} \mathrm{N}\right.$; $\left.24^{\circ} 06^{\prime} 30^{\prime \prime} \mathrm{E}\right)$, the Põlluotsa site $\left(59^{\circ} 12^{\prime} 10^{\prime \prime} \mathrm{N}\right.$; $\left.24^{\circ} 05^{\prime} 50^{\prime \prime} \mathrm{E}\right)$, the Vandjala Mire $\left(59^{\circ} 26^{\prime} 00^{\prime \prime} \mathrm{N}\right.$; $\left.2^{\circ} 03^{\prime} 30^{\prime} \mathrm{E}\right)$, the Saha-Loo Bog

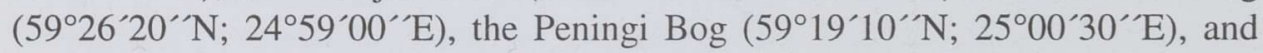
the Merivälja Mire $\left(59^{\circ} 29^{\prime} 45^{\prime \prime} \mathrm{N}\right.$; $\left.24^{\circ} 51^{\prime} 40^{\prime \prime} \mathrm{E}\right)$ do not contain any diatoms. Preisolation sediments are missing in the Harku Mire $\left(59^{\circ} 23^{\prime} 00^{\prime \prime} \mathrm{N}\right.$; $\left.24^{\circ} 36^{\prime} 00^{\prime \prime} \mathrm{E}\right)$, 


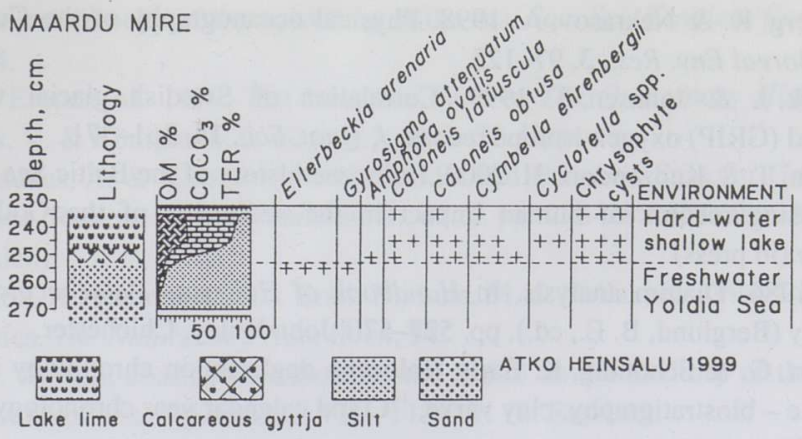

Fig. A6. Diatom diagram of the sediment core from the Maardu Mire.

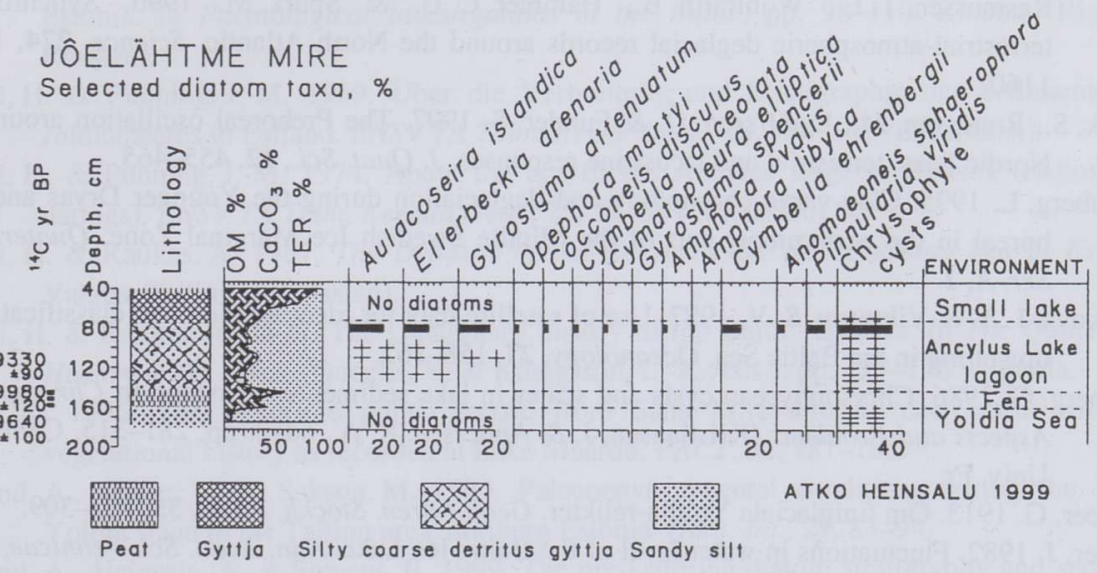

Fig. A7. Diatom diagram of the sediment core from the Jõelähtme site.

the Männiku Bog $\left(59^{\circ} 19^{\prime} 00^{\prime \prime} \mathrm{N}\right.$; $\left.24^{\circ} 44^{\prime} 00^{\prime \prime} \mathrm{E}\right)$, Lake Laanemaa $\left(59^{\circ} 09^{\prime} 15^{\prime \prime} \mathrm{N}\right.$; $\left.24^{\circ} 13^{\prime} 00^{\prime} \mathrm{E}\right)$, the Ääsmäe Mire $\left(59^{\circ} 14^{\prime} 30^{\prime} \mathrm{N}\right.$; $\left.24^{\circ} 34^{\prime} 00^{\prime} \mathrm{E}\right)$, the Kiili Mire $\left(59^{\circ} 18^{\prime} 20^{\prime \prime} \mathrm{N} ; 24^{\circ} 52^{\prime} 30^{\prime \prime} \mathrm{E}\right)$, and the Kulli Mire (59 $\left.23^{\prime} 30^{\prime \prime} \mathrm{N} ; 24^{\circ} 59^{\prime} 45^{\prime \prime} \mathrm{E}\right)$.

\section{REFERENCES}

Abelmann, A. 1985. Palökologische und ökostratigraphische Untersuchungen von Diatomeenassoziationen an holozänen Sedimenten der zentralen Ostsee. Berichte - Reports, Geol.Paläontol. Inst. Univ. Kiel, 9.

Åker, K., Eriksson, B., Grönlund, T. \& Kankainen, T. 1988. Sediment stratigraphy in the northern Gulf of Finland. Geol. Surv. Finland Spec. Pap., 6, 101-117. 
Alenius, P., Myrberg, K. \& Nekrasov, A. 1998. Physical oceanography of the Gulf of Finland: a review. Boreal Env. Res., 3, 97-125.

Andrén, T., Björck, J. \& Johnsen, S. 1999. Correlation of Swedish glacial varves with the Greenland (GRIP) oxygen isotope record. J. Quat. Sci., 14, 361-371.

Andrén, E., Andrén, T. \& Kunzendorf, H. 2000. Holocene history of the Baltic Sea as a background for assessing records of human impact in the sediments of the Gotland Basin. The Holocene (in press).

Battarbee, R. W. 1986. Diatom analysis. In Handbook of Holocene Palaeoecology and Palaeohydrology (Berglund, B. E., ed.), pp. 527-570. John Wiley, Chichester.

Björck, J., Possnert, G. \& Schoning, K. Early Holocene deglaciation chronology in Västergötland and Närke - biostratigraphy, clay varve, ${ }^{14} \mathrm{C}$ and calendar year chronology. Quat. Sci. Rev. (accepted).

Björck, S. 1979. Late Weichselian stratigraphy of Blekinge, SE Sweden, and water level changes in the Baltic Ice Lake. Lundqua Thesis, 7.

Björck, S. 1995. A review of the history of the Baltic Sea, 13.0-8.0 ka BP. Quat. Int., 27, 19-40.

Björck, S., Kromer, B., Johnsen, S., Bennike, O., Hammarlund, D., Lemdahl, G., Possnert, G., Rasmussen, T. L., Wohlfarth, B., Hammer, C. U. \& Spurk, M. 1996. Synchronized terrestrial-atmospheric deglacial records around the North Atlantic. Science, 274, 11551160.

Björck, S., Rundgren, M., Ingólfsson, Ó. \& Funder, S. 1997. The Preboreal oscillation around the Nordic Seas: terrestrial and lacustrine responses. J. Quat. Sci., 12, 455-465.

Brunnberg, L. 1995. Clay-varve chronology and deglaciation during the Younger Dryas and Preboreal in the easternmost part of the Middle Swedish Ice Marginal Zone. Quaternaria. Ser. A, 2.

Bychkova, I. A. \& Viktorov, S. V. 1987. Use of satellite data for identification and classification of upwelling in the Baltic Sea. Oceanology, 27, 158-162.

Cronberg, G. 1986. Chrysophycean cysts and scales in lake sediments: a review. In Chrysophytes: Aspects and Problems (Kristiansen, J. \& Andersen, R. A., eds.), pp. 281-315. Cambridge Univ. Pr.

De Geer, G. 1913. Om finiglaciala Yoldia-relikter. Geol. Fören. Stockh. Förh., 35, 307-309.

Donner, J. 1982. Fluctuations in water level of the Baltic Ice Lake. Ann. Acad. Sci. Fennicae, A III, 134, 13-28.

Duff, K. E., Zeeb, B. A. \& Smol, J. P. 1995. Atlas of Chrysophycean Cysts. Kluwer Acad. Publ., Dordrecht.

Eronen, M. 1974. The history of the Litorina Sea and associated Holocene events. Soc. Sci. Fennica, Comm. Phys.-Math., 44, 79-195.

Eronen, M. 1983. Late Weichselian and Holocene shore displacement in Finland. In Shorelines and Isostasy (Smith, D. E. \& Dawson, A. L., eds.), pp. 183-207. Academic Pr., London.

Eronen, M. \& Haila, H. 1982. Shoreline displacement near Helsinki, southern Finland, during the Ancylus Lake stage. Ann. Acad. Sci. Fennicae, A III, 134, 111-129.

Gidhagen, L. 1987. Coastal upwelling in the Baltic Sea. Satellite and in situ measurements of seasurface temperatures indicating coastal upwelling. Estuar. Coast. Shelf Sci., 24, 449-462.

Grönlund, T. 1991. The diatom stratigraphy of the Eemian Baltic Sea on the basis of sediment discoveries in Ostrobothnia, Finland. Geol. Surv. Finland, Rep. Inv., 102.

Haapala, J. 1994. Upwelling and its influence on nutrient concentration in the coastal area of the Hanko Peninsula, entrance of the Gulf of Finland. Estuar. Coast. Shelf Sci., 38, 507-521.

Hang, T. 1997. Clay varve chronology in the Eastern Baltic area. GFF, 119, 295-300.

Heinsalu, A., Veski, S. \& Vassiljev, J. 2000. Palaeoenvironment and shoreline displacement on Suursaari Island, Gulf of Finland. Bull. Geol. Soc. Finland (in press). 
Hela, I. 1976. Vertical velocity of the upwelling in the sea. Soc. Sci. Fennica, Comm. Phys.-Math., 46, 9-24.

Hyvärinen, H. \& Eronen, M. 1979. The Northern Part. In The Quaternary History of the Baltic (Gudelis, V. \& Königsson, L.-K., eds.), pp. 7-27. Uppsala.

Hyvärinen, H., Raukas, A. \& Kessel, H. 1992. Yoldia and Echeneis Seas. In Geology of the Gulf of Finland (Raukas, A. \& Hyvärinen, H., eds.), pp. 276-282. Estonian Acad. Sci., Tallinn (in Russian).

Ingerpuu, N., Kalda, A., Kannukene, L., Krall, H., Leis, M. \& Vellak, K. 1994. List of the Estonian bryophytes. The Naturalist's Note Book, 94.

Kessel, H. 1961a. Ancient coastal formations of the Baltic on the territory of the Estonian S.S.R. ENSV TA Geol. Inst. Uurimused, VIII, 113-131 (in Russian).

Kessel, H. 1961b. Balti mere arenemisest Eesti NSV territooriumil Holotseenis. ENSV TA Geol. Inst. Uurimused, VII, 167-185.

Kessel, H. \& Miidel, A. 1973. On the late and post-glacial crustal movements in Estonia. ENSV TA Toim. Keem. Geol., 22, 257-264 (in Russian).

Kessel, H. \& Pork, M. 1971. On the biostratigraphy of bottom sediments of the Baltic Sea in Estonia. In Palynological Investigations in the Baltic, pp. 98-110. Zinatne, Riga (in Russian).

Kessel, H. \& Punning, J.-M. 1969. Über die Verbreitung und Stratigraphie der Sedimente des Joldiameeres in Estland. ENSV TA Toim. Keem. Geol., 18, 154-163 (in Russian).

Kessel, H. \& Punning, J.-M. 1974. About the age of the Ancylus stage in Estonia (radiometric datings). ENSV TA Toim. Keemia Geol., 23, 59-64 (in Russian).

Kessel, H. \& Raukas, A. 1967. The Deposits of the Ancylus Lake and Littorina Sea in Estonia. Valgus, Tallinn (in Russian).

Kessel, H. \& Raukas, A. 1979. The Quaternary history of the Baltic. Estonia. In The Quaternary History of the Baltic (Gudelis, V. \& Königsson, L.-K., eds.), pp. 127-146. Uppsala.

Kihno, K. 1996. The Holocene pollen record from Saha Mire and its correlation with the vegetational history as recorded at Lake Maardu. PACT, 51, 181-188.

Lepland, A., Miller, U. \& Sakson, M. 1995. Palaeoenvironmental conditions during the Baltic Yoldia stage in the Tallinn area, northern Estonia. Quat. Int., 27, 83-94.

Lepland, A., Heinsalu, A. \& Stevens, R. 1999. The pre-Littorina diatom stratigraphy and sediment sulphidisation record from the west-central Baltic Sea: implications of the water column salinity variations. $G F F, \mathbf{1 2 1}, 57-65$.

Miller, U. \& Persson, C. 1973. A lump of clay embedded in glacial intermorainic sand. Geol. Fören. Stockh. Förh., 95, 342-346.

Palmén, E. 1930. Untersuchungen über die Strömungen in den Finnland umgebenden Meeren. Soc. Sci. Fennica, Comm. Phys.-Math., 12.

Poska, A. 1994. Three pollen diagrams from coastal Estonia. Kvartärgeol. Avd. Upps. Univ., 170.

Punning, J.-M., Rajamäe, R., Ehrenpreis, M. \& Sarv, L. 1977. Tallinn radiocarbon dates IV. Radiocarbon, 19, 111-117.

Raukas, A. 1994. Yoldia stage - the least clear interval in the Baltic Sea history. Baltica, 8, 5-14.

Raukas, A. 1995. Evolution of the Yoldia Sea in the eastern Baltic. Quat. Int., 27, 99-102.

Ristaniemi, O. \& Glückert, G. 1987. The Ancylus transgression in the area of Espoo - the first Salpausselkä, southern Finland. Bull. Geol. Soc. Finland, 59, 45-69.

Robertson, A.-M. 1990. The diatom flora of the Yoldia sediments in the Närke province, south central Sweden. Nova Hedwigia, 100, 255-262.

Saarnisto, M., Grönlund, T. \& Ekman, I. 1995. Lateglacial of Lake Onega - contribution to the history of the eastern Baltic basin. Quat. Int., 27, 111-120. 
Saarse, L., Heinsalu, A. \& Lang, V. 1996a. The Maardu area, northern Estonia: geological and environmental setting. PACT, 51, 115-122.

Saarse, L., Veski, S., Lang, V., Heinsalu, A., Hiie, S., Kihno, K., Rajamäe, R., Sakson, M. \& Sandgren, P. 1996b. Reconstruction of the environmental history of the Maardu area, northern Estonia, during the Holocene. PACT, 51, 205-216.

Saarse, L., Heinsalu, A., Poska, A., Veski, S., Rajamäe, R., Hiie, S., Kihno, K. \& Martma, T. 1997. Early Holocene shore displacement of the Baltic Sea east of Tallinn (N Estonia). Baltica, 10, 13-24.

Saarse, L., Heinsalu, A., Poska, A., Veski, S. \& Rajamäe, R. 1999. Palaeoecology and human impact in the vicinity of Lake Kahala, northern Estonia. PACT, 57, 373-403.

Sakson, M. 1996. Diatom studies of the Lake Maardu sediments, northern Estonia. PACT, 51, 151-155.

Sarv, A. \& Ilves, E. 1971. Radiocarbon dating of bog-lacustrine deposits of the Vaharu Bog (northwestern Estonia). In Palynological Investigations in the Baltic, pp. 143-149. Zinatne, Riga (in Russian).

Sauramo, M. 1958. Die Geschichte der Ostsee. Ann. Acad. Sci. Fennicae, A III, 51.

Smol, J. P. 1988. Chrysophycean microfossils in paleolimnological studies. Palaeogeogr. Palaeoclimatol. Palaeoecol., 62, 287-297.

Smol, J. P. 1995. Application of chrysophytes to problems in paleoecology. In Chrysophyte Algae. Ecology, Phylogeny and Development (Sandgren, C. D., Smol, J. P. \& Kristiansen, J., eds.), pp. 303-329. Cambridge Univ. Pr.

Snoeijs, P. (ed.). 1993. Intercalibration and distribution of diatom species in the Baltic Sea, Vol. 1. The Baltic Marine Biologist Publ., 16a.

Snoeijs, P. \& Potapova, M. (eds.). 1995. Intercalibration and distribution of diatom species in the Baltic Sea, Vol. 3. The Baltic Marine Biologist Publ., 16c.

Snoeijs, P. \& Vilbaste, S. (eds.). 1994. Intercalibration and distribution of diatom species in the Baltic Sea, Vol. 2. The Baltic Marine Biologist Publ., 16b.

Stabell, B. 1985. The development and succession of taxa within the diatom genus Fragilaria Lyngbye as a response to basin isolation from the sea. Boreas, 14, 273-286.

Svensson, N.-O. 1989. Late Weichselian and Early Holocene shore displacement in the central Baltic, based on stratigraphical and morphological records from eastern Småland and Gotland, Sweden. Lundqua Thesis, 25.

Svensson, N.-O. 1991. Late Weichselian and Early Holocene shore displacement in the central Baltic Sea. Quat. Int., 9, 7-26.

Valovirta, V. 1965. Zur spätquartären Entwicklung Südost-Finnlands. Bull. Comm. géol. Finlande, 220.

Veski, S. 1998. Vegetation history, human impact and palaeogeography of West Estonia. Pollen analytical studies of lake and bog sediments. Striae, $\mathbf{3 8}$.

Vos, P. C. \& de Wolf, H. 1993. Diatoms as a tool for reconstructing sedimentary environments in coastal wetlands; methodological aspects. Hydrobiologia, 269/270, 285-296.

Wastegård, S. 1996. Yoldia Sea foraminiferal and ostracode fossil fauna in eastern central Sweden. $G F F, 118, \mathrm{~A} 71-\mathrm{A} 72$.

Wastegård, S. \& Schoning, K. 1997. Calcareous fossils and radiocarbon dating of the saline phase of the Yoldia Sea stage. GFF, 119, 245-248.

Wastegård, S., Andrén, T., Sohlenius, G. \& Sandgren, P. 1995. Different phases of the Yoldia Sea in the north-western Baltic Proper. Quat. Int., 27, 121-129.

Wastegård, S., Björck, J. \& Risberg, J. 1998. Deglaciation, shore displacement and early-Holocene vegetation history in eastern middle Sweden. The Holocene, 8, 433-441. 


\title{
JOLDIAMERE DIATOMEE STRATIGRAAFIA JA PALEOKESKKOND PÕHJA-EESTIS
}

\section{Atko HEINSALU}

Ränivetika meetodil analüüsitud kahekümne Põhja-Eesti setteläbilõike põhjal rekonstrueeriti Joldiameres valitsenud keskkonnatingimusi. Joldiamere arengus eristati kolm etappi. Joldiamere alguses, umbes 10 300-9900 radiosüsiniku aastat tagasi $\left({ }^{14} \mathrm{C}\right.$ a.t.), oli Põhja-Eesti rannikumeri mageveeline. Joldiamere keskmisel etapil, umbes $9900-9750{ }^{14} \mathrm{C}$ a.t., tekkis soolase vee sissevoolu tagajärjel riimveeline keskkond. Joldiamere viimane etapp, umbes $9750-9500{ }^{14} \mathrm{C}$ a.t., oli uuesti mageveeline. Joldiamerest isoleerunud rannajärved olid madalad, rohketoitelised ja kalgiveelised.

\section{ДИАТОМОВАЯ СТРАТИГРАФИЯ И ПАЛЕОСРЕДА ИОЛЬДИЕВОГО МОРЯ В СЕВЕРНОЙ ЭСТОНИИ}

\author{
Атко ХЕЙНСАЛУ
}

На основании данных диатомовых анализов, отобранных из 20 разрезов Северной Эстонии, реконструирована палеосреда Иольдиевого моря. По палеосреде его развитие разделено на три стадии. В начальной стадии, примерно $10300-9900{ }^{14} \mathrm{C}$ лет т. н., прибрежное море было пресное; в средней стадии, примерно $9900-9750{ }^{14} \mathrm{C}$ лет т. н., в результате притока океанических вод здесь сформировалась соленовато-водная среда; в последней стадии, примерно $9750-9500{ }^{14} \mathrm{C}$ лет т. н., Иольдиевое море снова опреснилось. Изолированные от него прибрежные озера были неглубокие, и степень их насыщенности питательными компонентами и ионами была высокая. 